\title{
Evaluation of Metalworking Fluid Exposure and Dermatitis among Rifle Barrel Manufacturing Employees
}

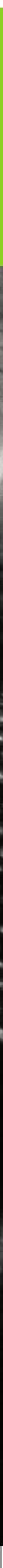

HHE Report No. 2014-0170-3263

December 2016

Loren C. Tapp, MD, MS Kendra Broadwater, MPH

Charles A. Mueller, MS

U.S. Department of Health and Human Services Centers for Disease Control and Prevention

National Institute for Occupational Safety and Health

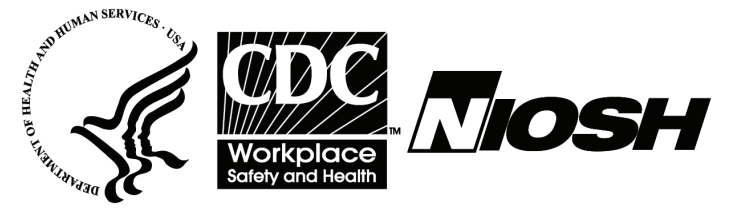




\section{Contents}

Highlights.

Abbreviations ...................................... iii

Introduction ............................................ 1

Methods ............................................... 3

Results ................................................ 6

Discussion ........................................ 21

Conclusions ....................................... 23

Recommendations.......................... 24

Appendix A ....................................... 28

Appendix B ........................................ 31

Appendix C ......................................... 33

References................................................ 36

Acknowledgements........................ 43

The employer is required to post a copy of this report for 30 days at or near the workplace(s) of affected employees. The employer must take steps to ensure that the posted report is not altered, defaced, or covered by other material.

The cover photo is a close-up image of sorbent tubes, which are used by the HHE Program to measure airborne exposures. This photo is an artistic representation that may not be related to this Health Hazard Evaluation. Photo by NIOSH. 


\section{Highlights of this Evaluation}

The Health Hazard Evaluation Program received a request from a manager at a rifle barrel manufacturing company. The manager was concerned about skin irritation and rashes among employees who were exposed to metalworking fluids. We visited the facility in August 2014 and November 2014.

\section{What We Did}

- We observed work practices and personal protective equipment use.

- We reviewed illness and injury logs, workers' compensation claims, and air sampling reports.

- We interviewed 46 employees about work and medical concerns and looked at employees' rashes.

- We took personal air samples for metalworking fluid mist and endotoxin. We asked sampled employees to complete a symptom survey after their work shift.

- We asked all employees to complete a questionnaire about their work exposures and possible work-related symptoms.

\section{What We Found}

- Many employees had skin exposure to metalworking fluids, including oils and coolant, and to rust inhibitor.

- Several current and former primary area employees had a history of rash from skin exposure to oil.

- Employees with skin exposure to coolant had more work-related dermatitis than employees without skin exposure to coolant.

- Ten production employees reported workrelated asthma-like symptoms (chest tightness or wheeze that improves away from work).

We evaluated exposure to metalworking fluid and dermatitis among employees at a gun barrel manufacturing facility. One metalworking fluid mist level was measured at the occupational exposure limit. Some production employees reported work-related asthma-like symptoms. We also found that skin exposure to metalworking fluid contributed to dermatitis. We recommend limiting skin and respiratory exposure to metalworking fluid by improving metalworking fluid mist control, changing manual handling practices, and improving access to and consistent use of gloves. Additionally, encouraging employees to report possible work-related symptoms early may prevent more serious problems.

- Two shipping employees reported work-related asthma-like symptoms.

- Work-related asthma-like symptoms may be related to exposures to metalworking fluid or other contaminants in the facility.

- One metalworking fluid mist level in the air reached the recommended limit during our visit. 
- The highest metalworking fluid mist levels occurred in the milling and chambering departments.

\section{What the Employer Can Do}

- Provide drilling employees with additional tools to reduce handling of oil-covered metal chips.

- Provide computer numerical control machining employees with tools they can use to dip parts into rust inhibitor.

- Establish a complete metalworking fluid maintenance program and include mist collector maintenance.

- Repeat air monitoring yearly and when processes change or production increases. If levels are more than half the recommended exposure limit, repeat monitoring every 6 months.

- Start a medical surveillance program for employees who are exposed to metalworking fluids.

- Train employees on the hazards of metalworking fluids and ways to avoid skin exposure when they are hired and repeat training once every year.

- Make gloves more accessible to production employees and enforce their use when there is direct contact with metalworking fluid.

\section{What Employees Can Do}

- Use tools and gloves to avoid skin contact with metalworking fluids and rust inhibitor.

- Wash skin with soap and water if metalworking fluid (coolant or oil) or rust inhibitor gets on your skin.

- Do not wash your hands with solvent.

- Tell your supervisor if you notice early signs of skin problems or respiratory symptoms that you think may be related to work. Taking action early may prevent more serious problems. 


\section{Abbreviations}

ACGIH ${ }^{\circledR} \quad$ American Conference of Governmental Industrial Hygienists

ANSI

American National Standards Institute

BLS

Bureau of Labor Statistics

CFR

Code of Federal Regulations

$\mathrm{CFU} / \mathrm{mL}$

Colony forming units per milliliter

CI

Confidence intervals

$\mathrm{CNC}$

Computer numerical control

$\mathrm{EU} / \mathrm{m}^{3}$

Endotoxin units per cubic meter

ISEA

International Safety Equipment Association

$\mathrm{mg} / \mathrm{m}^{3}$

Milligrams per cubic meter

MWF

Metalworking fluid

NAICS

North American Industry Classification System

$\mathrm{NIOSH}$

National Institute for Occupational Safety and Health

OEL

Occupational exposure limit

OSHA

Occupational Safety and Health Administration

PPE

Personal protective equipment

PR

Prevalence ratios

REL Recommended exposure limit

TLV $\mathbb{R}$

Threshold limit value

TWA

Time-weighted average

WEELTM

Workplace environmental exposure level 
This page left intentionally blank 


\section{Introduction}

The Health Hazard Evaluation Program received a request from managers at a rifle barrel manufacturing company. The request concerned skin irritation and rashes among production employees who were exposed to metalworking fluids (MWFs). We visited the facility in August and November 2014 to assess MWF exposures and learn more about employee symptoms and health concerns. We sent letters summarizing our preliminary findings and recommendations in August 2014 and November 2014. We provided employees with their own exposure results and the employer with summary exposure results in February 2015 and November 2016.

\section{Background}

The rifle barrel manufacturing company began operating in 1976 and moved to the current 100,000-square-foot-building in 1995. The building was divided into two production areas on the first floor and administrative offices on the second floor. At the time of our visits, 86 nonunion employees worked across two 10-hour shifts Monday through Thursday.

In 2012, higher demand for the product led the company to hire more employees (up to 200) and institute two 10-hour work shifts per day. Since then, the number of employees has fluctuated between 80 and 200 depending on production demands. Between 2013 and 2014, three informal, confidential complaints were made to the Occupational Safety and Health Administration (OSHA) about lack of access to personal protective equipment (PPE), skin and breathing problems, and exposure to MWF. OSHA did not inspect the facility, but requested by letter that the company investigate, make needed corrections, and document its findings and modifications in writing. At the suggestion of OSHA, the company requested a National Institute for Occupational Safety and Health (NIOSH) health hazard evaluation.

\section{Metalworking Fluids}

This facility mainly used two types of MWFs, a mineral oil-based MWF they refer to as "oil" and a semisynthetic water-based MWF they refer to as "coolant," wording we have maintained in this report. Inhalation of MWF aerosols may irritate the throat, nose, and lungs and has been associated with chronic respiratory problems. Skin contact with MWF may cause skin disorders. Detailed information on occupational exposure limits (OELs) and health effects from MWF exposure is presented in Appendix A.

\section{Process Description}

The two production areas were separated by a concrete wall with a large center passageway for moving materials from one side to the other. The front production area contained the shipping department that had large bay doors for receiving raw materials (stainless steel and steel alloy cylinders) and shipping finished rifle barrels. The sawing, and secondary production processes (chambering, milling, and stamping departments) were located adjacent to the shipping department. The back production area contained the primary production processes (drilling, reaming, and rifling departments), the clean and inspect stations, the 
ovens, and the lathe department (a secondary production process). Rifle barrels were inspected at each step. The barrels were heated at prescribed times during manufacturing to relieve stress and increase strength. Most employees worked in only one department.

\section{Sawing}

After receipt, stock metal bars were cut to length according to the design specifications for the rifle barrel order. Stock metal bars came in a variety of steel alloys and stainless steel alloys. Semisynthetic water-based MWF ("coolant") was used during stock metal sawing (cutting). Two or three employees worked in sawing.

\section{Primary Production: Drilling, Reaming, and Rifling}

Cut metal bars were sent to primary production to machine and finish the inside of the rifle barrel. The machines used Garia® 2600 M-12, a 30\%-60\% mineral oil-based MWF ("oil”") to reduce heat, lubricate, and remove metal chips during drilling. The company started using this oil in September 2013; previously, the company used Met Drill 744 cutting oil. During drilling, the oil was applied to the site of action through the end of the drill bit at about 1,000 pounds per square inch. The stock bar rotated several thousand times a minute while the hole was drilled. The oil was filtered and recycled at each machine reservoir. Drilling caused the temperature of the lubricating oil to increase. Using a heat exchange system, the heat from the lubricating oil was either exhausted out of the building or used to heat the building, depending on the season. The drill created a bore slightly smaller than the diameter required in the order specifications. Ten employees worked in drilling. The reaming machines ensured that the appropriate bore diameter was reached and was uniform for the length of the barrel. The reaming machines also put a finer finish on the interiors of the barrels. The reaming bits rotated at a slower rate than during drilling, fewer than 500 rotations per minute. Oil was also used during this step but was applied at a lower pressure. Four employees worked in reaming.

In the rifling department, spiral grooves or "rifling" were added to the inside of the rifle barrel. Garia 2600 M-12 was used during cut rifling, and QualiChem Company Met-form 581 , another type of straight oil, was used in the button rifling machines. Met-form 581 contains $60 \%-80 \%$ alkanes and $20 \%-40 \%$ naphthenic petroleum distillates, which are both components of mineral oil. Other ingredients together may comprise up to $10 \%$ of the mixture, but each of these individually is less than $1 \%$ of the total mixture. Usually two employees worked in rifling.

\section{Clean and Inspect, Heat Treatment}

In each department, the supervisor inspected completed barrels. When barrels reached the final stage, they underwent a final inspection and cleaning. Employees cleaned barrels by dipping batches of them consecutively in three large drums of naphtha solvent. Barrels underwent heat treatment in ovens in the back production area. Barrels were placed in ovens in batches, where the temperature was gradually increased to 1,100 degrees Fahrenheit. Four to six employees cleaned, inspected, dipped, or heat treated rifle barrels. 


\section{Secondary Production: Lathing, Milling, and Chambering}

Secondary production processes machined and finished the outside of the barrel using computer numerical control (CNC) machines in the lathe and milling departments. Coolant was used to cool, lubricate, and remove chips in these two departments. Seven employees worked in lathe and five in milling. CNC chambering machines created threads and ammunition housing or "chambers" in the rifle barrels. Of the thirteen CNC chambering machines, nine used Garia 2600 M-12 oil as a MWF; the other four machines used coolant. Six employees worked in the chambering department. Most CNC-machined parts were dipped in Cimcool® Cimguard 10® corrosion inhibitor.

\section{Methods}

The objectives of our evaluation were to:

1. Assess employee health problems related to MWF exposure.

2. Assess workplace exposures to MWFs, endotoxin, and other workplace hazards.

3. Provide recommendations to reduce exposures and prevent work-related health problems.

In August 2014, we met with employer and employee representatives to discuss the health hazard evaluation request and learn more about their concerns. During the initial visit, we held confidential medical interviews; reviewed reports, records, and health and safety programs; observed employees doing their jobs; and looked at the ventilation system. We returned in November 2014 to collect air and bulk MWF samples, observe work practices and PPE use, administer a health questionnaire to employees, and collect post-shift symptom surveys.

\section{First Site Visit}

\section{Observations}

We observed work processes, practices, and conditions in the manufacturing and shipping areas. We noted what kinds of PPE were used, consistency of use, and how effective PPE was in preventing dermal exposure to MWF. We looked at the building ventilation and heat exchange system. We measured the temperature of MWF in reservoirs using a noncontact laser infrared thermometer at the beginning and end of the workday.

\section{Document Review}

We reviewed the following documents:

- Two consultants' reports concerning exposure to airborne MWF and microbes in bulk MWF

- OSHA complaint files from 2013-2014

- Company safety and health, hazard communication, and oil exposure and hygiene programs, including training materials

- Mist collector model information and maintenance information 
- Safety data sheets

- OSHA Form 300 Logs of Work-Related Injuries and Illnesses from 2011 through 2014.

\section{Nonfatal Injury and IIIness Rates}

We used data from the company's OSHA Logs and data from the Bureau of Labor Statistics (BLS) to calculate and compare incidence rates of nonfatal injury and illness between this facility and the U.S. small arms manufacturing industry as a whole (North American Industry Classification System [NAICS] Code 332994) for years 2011 and 2012. BLS does not provide data for NAICS 332994 for years 2013 and 2014, so we compared this facility's rates to NAICS 332990, all other U.S. fabricated metal product manufacturing, for years 2013 and 2014 [BLS 2016].

The incidence rates are for nonfatal injuries and illnesses per 100 full-time employees for each year. These rates are useful for comparing incidence to similar industries and tracking progress in preventing work-related injuries and illnesses. Incidence rates were calculated using the following formula [BLS 2016]:

Incidence rate $=$ number of injuries and illnesses $\times 200,000$ hours / employee hours worked annually

The "200,000 hours" in the formula represents the equivalent of 100 employees working 40 hours a week, 50 weeks a year. For the number of "employee hours worked annually," we used the number of annual work hours reported by the company on its OSHA 300A forms for each year from 2011-2014. These calculations and explanations can be found on the BLS website at http://data.bls.gov/iirc/.

\section{Medical Interviews and Medical Record Review}

We confidentially interviewed 46 of 47 production employees who worked with MWFs and were working on the dates of our visit. We asked about their medical and work history using a semi-structured interview form. We reviewed medical records of interviewed employees with health problems that might be work-related. We also reviewed medical records related to workers' compensation claims submitted from 2010 through 2014.

\section{Second Site Visit}

\section{Observations}

We observed work practices and conditions in the manufacturing departments. We noted changes in work practices and PPE use since our first visit.

\section{Sampling for Metalworking Fluid and Endotoxin}

We collected personal air samples for thoracic-sized particles and endotoxin in the production, quality control, engineering, and shipping departments. Endotoxin is a compound released from certain bacteria when they die or multiply and is believed to cause respiratory illness. Health effects and exposure limits related to endotoxin exposure are discussed in Appendix A. 
We collected 25 personal air samples for thoracic-sized particles and MWF mist and 7 personal air samples for endotoxin on the first day of the site visit. We collected 19 personal air samples for thoracic-sized particles and MWF mist and 2 personal air samples for endotoxin on the second day of the site visit. All personal samples were full shift (ranging 7 hours 11 minutes to 10 hours) except one partial shift sample for endotoxin on a shipping employee ( 2 hours 17 minutes). Thoracic-sized particles have an aerodynamic diameter of 30 micrometers or less and can reach deeper parts of the lungs than larger particles. We collected 8 bulk MWF samples for endotoxin analysis.

The personal thoracic-sized particle air samples were collected and analyzed by gravimetric analysis per NIOSH Method 5524 [NIOSH 2016]. After the filter was gravimetrically weighed, a ternary solvent blend was used to extract the MWF fraction from each sample. Endotoxin personal air samples were collected using an endotoxin-free three-piece 37-millimeter closed-face cassette, preloaded with 0.45-micrometer-pore-size polycarbonate filters at 2 liters per minute. We collected bulk MWF samples using a sterile pipette to fill a 4-ounce sterile bottle. These samples were kept on ice and shipped within 1 day to the laboratory for analysis. Samples were analyzed for endotoxin content with the kineticchromogenic procedure using the limulus amebocyte lysate assay [Cambrex 2005]. For these analyses, one endotoxin unit (EU) was equivalent to 0.053 nanograms of endotoxin. The limit of detection was $0.50 \mathrm{EU}$ per sample.

\section{Questionnaires}

We asked all 80 employees at the facility to complete a written questionnaire; 79 participated. The questionnaire included questions from the European Community Respiratory Health Survey [Grassi et al. 2003] and questions modified from the Nordic Occupational Skin Questionnaire [Susitaival et al. 2003]. The questionnaire asked about demographic information, work and medical history, PPE use, hygiene habits, and personal exposures. We also asked about skin, nasal, and respiratory symptoms in the month prior and in the 12 months prior to the questionnaire, and whether these symptoms changed on days away from work. Self-reported symptoms that improved on days away from work could indicate work relatedness and were defined as work-related symptoms.

We created a combination variable, which we called "asthma-like symptoms." This definition may include people who have not been diagnosed as having asthma [Grassi et al. 2003]. Asthma-like symptoms were defined as any of the following:

- current use of asthma medicine

- wheezing or whistling in the chest in the past 12 months

- awakening with a feeling of chest tightness in the past 12 months

- an attack of asthma in the past 12 months

We created another variable called "work-related asthma-like symptoms." Work-related asthma-like symptoms were defined as any of the asthma-like symptoms that improved away from work. For each of the bulleted items above, we asked if the symptom had improved away from work. Work-related asthma-like symptoms were defined as having one or more of 
the following:

- Less use of asthma medicine when away from work

- Wheezing or whistling in the chest in the past 12 months that improves away from work

- Awakening with a feeling of chest tightness in the past 12 months that improves away from work

- Attacks of asthma in the past 12 months that are less frequent away from work

We analyzed the data using SAS statistical software version 9.3 to evaluate relationships between exposures (oil and coolant) and symptoms (respiratory and skin). When looking at skin symptoms, we put employees into exposure groups on the basis of responses to questions about handling oil, coolant, or parts wet with oil or coolant. When looking at respiratory symptoms, we put employees into exposure groups based on job title as a surrogate for airborne oil and coolant exposures. We calculated prevalence ratios (PR) and $P$ values using Fisher's exact test or chi-square test to determine the statistical significance of the relationships between MWF exposure groups and symptom prevalence. We also calculated $95 \%$ confidence intervals (CI). The prevalence ratio is the prevalence of the symptom in the exposed group divided by the prevalence of the symptom in the comparison group. Statistical significance was set at $P<0.05$. When there were sufficient data, we evaluated confounding and effect modification factors by stratified analyses. In addition, we evaluated the relationship between frequency of MWF skin exposure and work-related dermatitis prevalence using the Cochran-Armitage trend test.

\section{Comparing Post-shift Symptom Surveys and Sampling Results}

We administered post-shift symptom surveys over 2 consecutive days to production employees who participated in personal air sampling. The surveys asked about pre-shift and post-shift skin, eye, and respiratory symptoms that employees may have experienced on the days of our evaluation. We defined new-onset symptoms as those present at the end of the shift but not present before the shift. We reported the frequency of each new-onset symptom for all completed surveys. We also looked at the relationship between airborne MWF levels and post-shift symptom occurrence. For new-onset symptoms reported by five or more employees, we used a linear mixed model to determine if there was an association between personal air MWF concentrations and the reported new-onset symptom.

\section{Results}

\section{First Site Visit}

\section{Observations}

\section{Work Practices and Equipment Design}

We observed that work practices and equipment design contributed to dermal exposure to oil and coolant on employees' hands, arms, legs, and feet. During reaming, oil streaming out the barrel being reamed was not well contained by the machine and frequently splashed onto 
the reaming operator. Some employees, particularly those working in reaming, wore long chemical-resistant aprons to protect their clothing against oil contamination. However, we observed oil dripping onto employees' lower pant legs below the aprons. Drilling, reaming, and rifling department employees manually handled oil-contaminated parts and removed chips from collection basins frequently throughout their shift (Figure 1). The company supplied machine operators with tools to scrape scrap metal chips into a pile before manually removing the scrap metal chips from drilling machines. Some employees used these tools, while others opted to use their gloved hands to gather chips from the machines. Additionally, most surfaces, including tools, machinery, and storage baskets in primary production areas (drilling, reaming, rifling) were covered in oil and not cleaned regularly. Incidental contact between most surfaces and bare skin would lead to contamination.

We observed that oil splashed or spilled onto the primary production floor throughout the workday, creating a slippery walking surface. In some cases, work practices, such as moving parts in and out of the machine, transporting parts via baskets, or scooping oil-covered metal chips from machines into bins, contributed to oil spills on the floor. Otherwise, oil splashed out of some of the machines onto the ground or onto employee aprons, eventually dripping to the ground. The main walkways were cleaned twice a day with a commercial floor cleaner to reduce the amount of oil on the floor surface and to reduce the risk of slips and falls. During our visit, we noted that the floor remained slick despite frequent cleaning and created a slip hazard in the drilling, reaming, and rifling departments and the walkways between them.

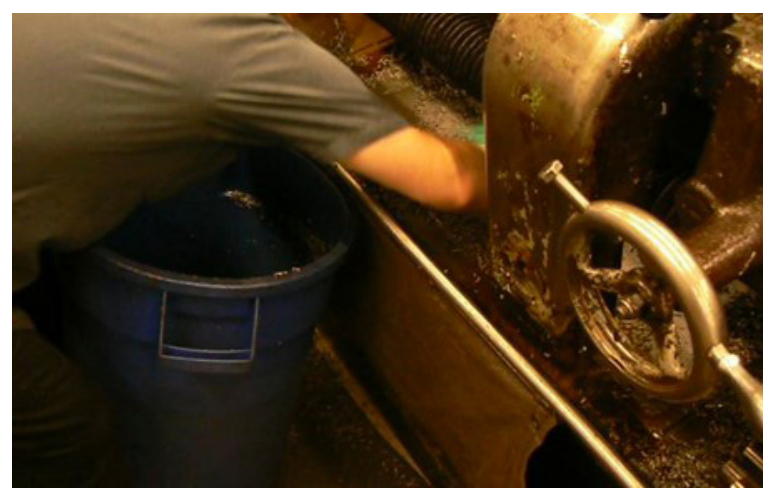

Figure 1. Employee with bare forearms removing metal chips from a drilling machine using his gloved hands.

\section{Personal Protective Equipment}

Employees were required to wear closed-toed, impact-resistant shoes and safety glasses. We observed some employees wearing short-sleeved shirts, sleeveless shirts, and short pants while working in production areas. The company provided gloves, but employees were not required to wear them. We observed all but one of the drilling, reaming, and rifling employees wearing gloves. 
Employees generally wore one of two types of nitrile gloves when handling parts wet with MWF: a 0.015 -inch thick (15 mil) cotton-lined green nitrile glove with a gauntlet cuff for oil exposure or a thinner black nitrile glove for coolant exposure. Per American National Standards Institute/ International Safety Equipment Association (ANSI/ISEA) standard 105-2011, the thick green nitrile gloves offer high protection against abrasion (rated 4 on a scale of 5), low protection against puncture (rated 1 on a scale of 5) and minimal cut protection against a blade (rated 0 on a scale of 5) [ANSI/ISEA 2011]. Employees could get gloves from a vendingstyle machine using their employee numbers. They could also get gloves from department supervisors or the tool crib manager. We observed an employee handling oil and parts covered in oil not wearing gloves and other employees handling parts wearing torn gloves. We observed employees emptying oil and metal chips from inside their gloves.

Some employees did not wear gloves while removing parts from the rust inhibitor product (Cimguard 10). We observed employees fully submersing both hands without gloves in Cimguard 10.

During some tasks, especially in the drilling department, we observed that oil and metal chips entered the glove at the cuff. Employees removed the metal chips by taking the gloves off and shaking them out. While this may remove larger metal chips, small chips and oil can remain inside the gloves and cut and contaminate employees' hands when they put the gloves back on. Most employees folded down the cuffs of the gauntlet-style thicker nitrile green gloves to make the gloves easier to remove and to prevent oil from running down the cuff of the gloves onto their arms when they raised their hands up. However, this practice also left the upper forearm exposed to oil. We saw some employees with oil on their forearms. We also observed that employees did not always wash oil off of their arms when they washed their hands.

The company provided employees with personal work uniforms to prevent soiling their street clothing. A contract uniform company delivered and laundered the uniforms every week. However, new employees were not given work uniforms until they had worked 90 days with the company. Employees received a work locker where they could keep their uniforms, street clothes, and personal effects.

Oil reservoir temperatures increased from the beginning of the shift to the end of the shift. The drilling and rifling department oil reservoirs warmed more than those in other departments. We found that the temperature of the MWFs varied between departments and within departments. The temperature reached $130^{\circ}$ Fahrenheit when operating under normal conditions in the drilling department. During our August 2014 site visit, we noted that one rifling machine was fitted with a 5-gallon bucket as an oil reservoir while the other machines had reservoirs of 15 gallons or larger. The temperature of the 5-gallon reservoir reached $140^{\circ}$ Fahrenheit, about $45^{\circ}$ Fahrenheit hotter than the larger reservoirs in the same department. Employees reported that the temperature of the oil in this rifling machine made handling the parts uncomfortably hot compared to working on other rifling machines. Prior to our second visit, the bucket was replaced with a larger reservoir, effectively reducing oil temperature. Maintaining MWF temperatures as low as feasible by using 15-gallon or larger reservoirs will ensure that parts are not excessively hot for handling. 


\section{Ventilation}

Supply air was provided to the production facility by large fans attached to fabric ducts whose length and diameter were adjusted using ropes. The fans brought 50,000 cubic feet per minute of outdoor air into the building, which was designed to be positively pressurized. During cold weather, the outdoor air was heated by a heat exchanging unit that conditioned incoming air using heat diverted from the oil reservoirs. When the heat exchanger was not used to heat incoming air, the heated air was exhausted out of the building from the heat exchanger. During our visit, several stationary pedestal fans operated in the drilling department to cool employees. They were positioned to draw air from the drilling area and blow the air toward duct openings in the exterior wall that housed non-operational fans, which have not worked for several years, including during our visit. Large articulated bay doors were opened to the outdoors in the secondary area during our evaluation. These doors are reportedly only kept closed during cold weather. Radiant heaters above the drilling department were used during winter. Employees noted that when the heaters were first turned on, typically on the first very cold day of fall or winter, the oil and dust accumulation burned off and filled the facility with thick smoke.

\section{Metalworking Fluid Maintenance}

According to managers, the oil in the drilling, reaming, and rifling machines was not changed regularly. MWF was changed only when it was obviously contaminated or developed an odor. The company had no written MWF maintenance plan. Additional oil was added to the reservoir as needed. Metal particles were removed from the MWF with custom bag filtration and magnets. The $\mathrm{pH}$ of the coolant used in the $\mathrm{CNC}$ machines was checked regularly and maintained within an operational range of 8.5 to 9.5 by adding coolant. $\mathrm{CNC}$ machines in the chambering department that used the Garia 2600 M-12 were equipped with mist collectors, which collected MWF mist and reduced ambient levels of MWF in the air.

\section{Document Review}

In 2012 and 2013, the company's insurance provider took eight full-shift personal samples for total MWF in air. The total MWF exposures ranged from 0.05 to 0.50 milligrams per cubic meter $\left(\mathrm{mg} / \mathrm{m}^{3}\right)$. One full-shift personal exposure measurement was equal to the NIOSH REL for total MWF mist of $0.50 \mathrm{mg} / \mathrm{m}^{3}$. This employee worked as a CNC machine operator, but the department was unspecified. Four personal measurements exceeded half of the NIOSH REL, or $0.25 \mathrm{mg} / \mathrm{m}^{3}$; these measurements were taken in the CNC $(n=2)$, reaming $(\mathrm{n}=1)$, and drilling $(\mathrm{n}=1)$ locations.

OSHA received three employee complaints in 2013 and 2014. The complaints were about skin and breathing exposure to MWF, improper maintenance of MWF, and lack of access to PPE. OSHA noted that several cases of dermatitis occurred after the Met-Drill 744 was replaced with the Garia $2600 \mathrm{M}-12$. As part of its response to OSHA in October 2013, the company provided sampling results from October 2008. In October 2008, the company took five full-shift personal air samples. Three drilling employees had total MWF exposures of $0.53,0.61$, and $0.68 \mathrm{mg} / \mathrm{m}^{3}$. Total MWF exposures for two employees in the CNC areas were 0.63 and $0.40 \mathrm{mg} / \mathrm{m}^{3}$. Four of the five measurements exceeded the NIOSH REL of $0.5 \mathrm{mg} / \mathrm{m}^{3}$ 
for total MWF particulate.

According to February 2013 sample results for bacteria provided to us by the company, one coolant sample contained 105 colony forming units per milliliter $(\mathrm{CFU} / \mathrm{mL})$. According to the coolant manufacturing company, the coolant system had been designed to be colonized by specific nonpathogenic bacteria [Blaser Swisslube Inc. 2013]. The Health and Safety Executive in the United Kingdom states that well-maintained MWFs should have bacterial concentrations below $10^{3} \mathrm{CFU} / \mathrm{mL}$ of fluid [HSE 2006]. Concentrations between $10^{3}$ and $10^{6}$ $\mathrm{CFU} / \mathrm{mL}$ indicate reasonable control, and concentrations greater than $10^{6} \mathrm{CFU} / \mathrm{mL}$ indicate poor control [HSE 2006].

We reviewed product information about the mist collectors used on CNC machines in the chambering department. The company had installed MistBusters ${ }^{\circledR}$ on CNC machines that use Garia $2600 \mathrm{M}-12$, which are all located in the chambering area. They had installed eight MistBuster Model 500 mist collectors and three MistBuster Model 850 mist collectors. Mist collectors are not used on CNC machines running the water-based coolant. The company does not perform scheduled maintenance on the mist collectors. The maintenance department stocks replacement elements. We learned from management that when a mist collector's performance declines and mist becomes visible in the air, the element is cleaned or replaced. The maintenance department does not keep records of when they are serviced or which elements are replaced. The manufacturer recommends periodic maintenance that includes cleaning the mist impingers and the electronic cell when they contain "excessive buildup." The manufacturer notes in the MistBuster manual that the frequency of maintenance depends on the operation and machines collecting water-based machining fluid will need to be cleaned more frequently than those collecting petroleum-based fluid [Air Quality Engineering 2016].

\section{Occupational Safety and Health Administration Injury and Illness Log Review}

We reviewed the company's OSHA 300 and 300A Logs from 2011 through 2014. Table 1 shows the number of employees, hours worked, and OSHA 300 Log entries during those years. 
Table 1. Numbers of hours worked, employees, and injury and illness entries reported on OSHA Logs from 2011 through 2014

\begin{tabular}{lcccc}
\hline & 2011 & 2012 & 2013 & 2014 \\
\hline Total \# employees & 119 & 171 & 225 & 110 \\
Total \# hours worked & 73,313 & 311,486 & 368,412 & 237,076 \\
Total \# of entries & 11 & 36 & 39 & 27 \\
Skin entries & 2 & 7 & 7 & 3 \\
Respiratory entries & 0 & 0 & 0 & 2 \\
Musculoskeletal sprains or strains & 3 & 16 & 20 & 9 \\
Lacerations, punctures, contusions, & 3 & 9 & 8 & 10 \\
abrasions & & & & 3 \\
Slips and falls & 0 & 0 & 1 & 0 \\
Musculoskeletal disorders & 0 & 0 & 2 & 0 \\
(cumulative trauma) & & & & \\
Other entries & 3 & 4 & 1 & \\
\hline
\end{tabular}

Musculoskeletal sprains/strains and lacerations/punctures/contusions/abrasions accounted for most entries for each year. Drilling operators accounted for 12 of the 19 skin entries over the 4 years. Primary machine operators other than drilling operators accounted for 5 skin entries (one reaming, one rifling, and three employees not designated to one primary machining type); one material handler and one saw operator accounted for the remaining two entries. One drilling operator and one $\mathrm{CNC}$ deburr operator accounted for the two respiratory entries.

\section{Comparing Nonfatal Injury and IIIness Rates to the U.S. Small Arms Manufacturing Industry}

Figure 2 compares the rates of workplace injuries and illnesses per 100 full-time workers between the facility and U.S. small arms manufacturing industry for years 2011 and 2012, and between the facility and all other fabricated metal product manufacturing for years 2013 and 2014, on the basis of company OSHA Logs and BLS data. This facility's rates were four to six times higher than the U.S. industry rates from 2011-2014. 


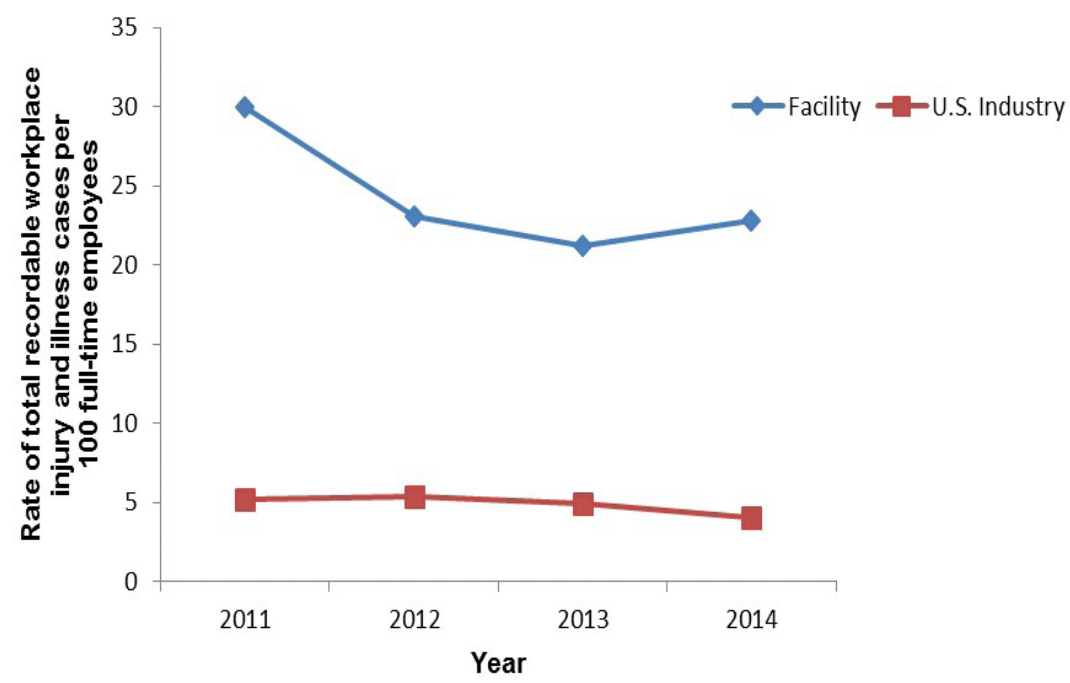

Figure 2. Comparing rates of workplace injuries and illnesses per 100 full-time workers between the facility and U.S. small arms manufacturing industry (NAICS 332994), years 2011-2012, and U.S. all other fabricated metal product manufacturing (NAICS 332990), years 2013-2014 [BLS 2016].

\section{Medical Interviews}

We confidentially interviewed 46 of the 47 production employees: 17 worked with CNC machines, 19 worked or inspected in drilling, reaming, or rifling (primary department), and 10 worked in other jobs including maintenance, saws, material handling, assembly/deburr, floating, stamping, and ovens. Among the 46 interviewed employees, 42 (91\%) were male, the mean age was 42 years (range: $21-65$ years), and the mean time worked at the facility was 5 years (range: 10 months-19 years).

Seventeen of the 46 employees reported having symptoms in the past year that they felt were work-related. Of these 17 employees, 11 described having a rash in the past year, 3 reported respiratory symptoms ( 1 with flu-like illness, 1 with chest heaviness at work, and 1 with dry cough at work), 2 reported nasal symptoms at work, and 1 reported a shoulder injury. Of the 11 employees reporting rash in the year prior to our site visit, all reported working in drilling, reaming, or rifling when their rash began and 8 reported that they thought the oil at work caused the rash. Of these 11 employees, 3 had a rash at the time of our interviews. On examination, red papules, pustules, and inflamed hair follicles were present on these employees' wrists and/or forearms, areas that were not covered by protective gloves. The skin examinations and employees' medical and work history provide evidence that many of these 11 employees' rashes were likely related to oil exposure at work. Two employees' skin lesions looked consistent with oil folliculitis (Figure 3). Of the three employees reporting work-related respiratory symptoms, two worked in $\mathrm{CNC}$ milling and one in maintenance. 


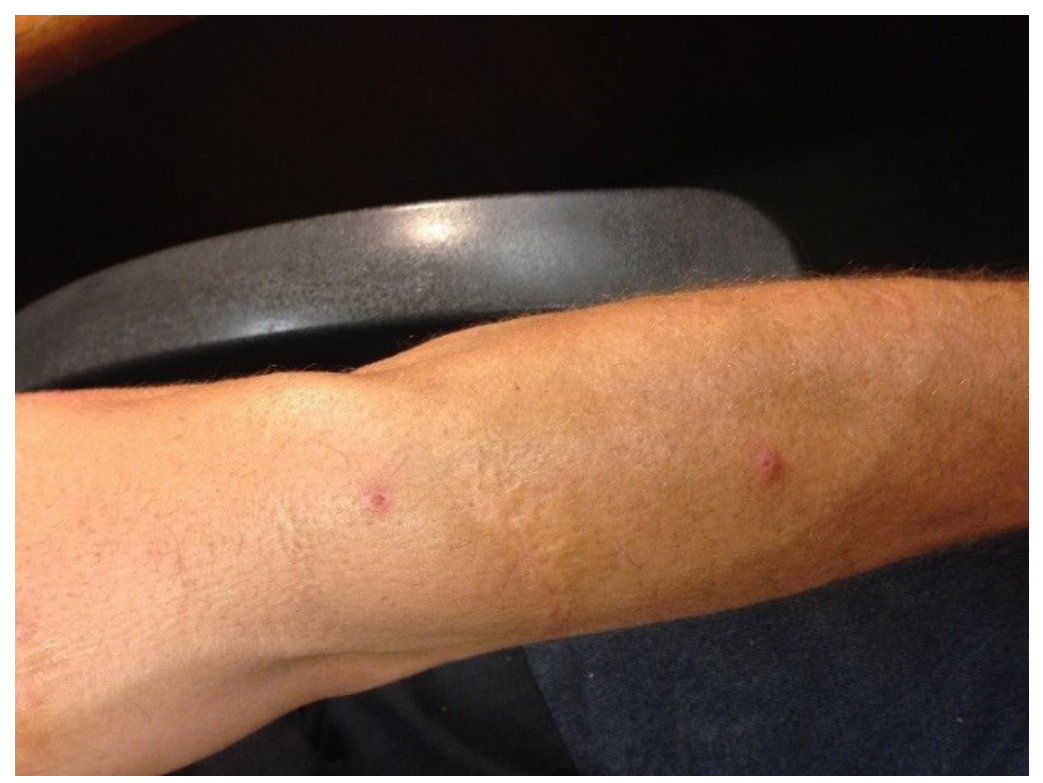

Figure 3. Two inflamed, reddened hair follicles (folliculitis) on forearm of employee working in primary production.

Additionally, during the interviews, some employees reported that gloves, especially the black nitrile gloves, were not easily accessible and they felt they were discouraged from asking for additional gloves during the work shift. Therefore, they would continue to wear their gloves when torn or contaminated inside. Some employees reported purchasing their own thin nitrile gloves to use at work.

\section{Medical Record and Workers' Compensation Claims Review}

We reviewed medical records from two interviewed employees and two former employees who reported experiencing skin or respiratory illness between 2010 and 2014, possibly related to work exposures. The two former employees had histories and physical examinations that were consistent with work-related contact dermatitis. These employees worked in primary production. A third employee, a CNC machinist, had a rash that was not work-related and respiratory symptoms that might have been related to work exposures. However, there was not enough information in the medical record to determine workrelatedness of the respiratory symptoms. A fourth employee, working as an inspector in primary production, was diagnosed with chronic obstructive pulmonary disease with bronchospasm that could have a work-related component.

We also reviewed medical records from thirteen (one current and twelve former) employees seen for workers' compensation claim examinations from 2010 through 2014 related to skin or respiratory illness. Of these thirteen employees, eleven were seen for rash only, one was seen for rash and respiratory symptoms (two different claims), and one employee was seen for respiratory symptoms. Of the twelve claims for rash, ten were determined to be related to oil exposure from work (eight occurred prior to September 2013 when the company changed the oil in the primary department), one was from a reaction to ingredients in gloves worn at work, and one was not work-related. Of the two respiratory claims, one was found 
to be related to particulate exposure at work, and the second was determined to be possibly aggravated by work but more likely from cardiopulmonary disease.

\section{Second Site Visit}

\section{Observations and Workplace Changes}

During our August 2014 site visit, we noted that oil splashes were common in the reaming department, regularly contaminating employees' clothing, especially pants below protective aprons on reaming operators. By November 2014, the employer had provided guards that employees placed on reaming machines manually after setting up the parts. The guards worked well in preventing oil from splashing out of the machines (Figure 4).

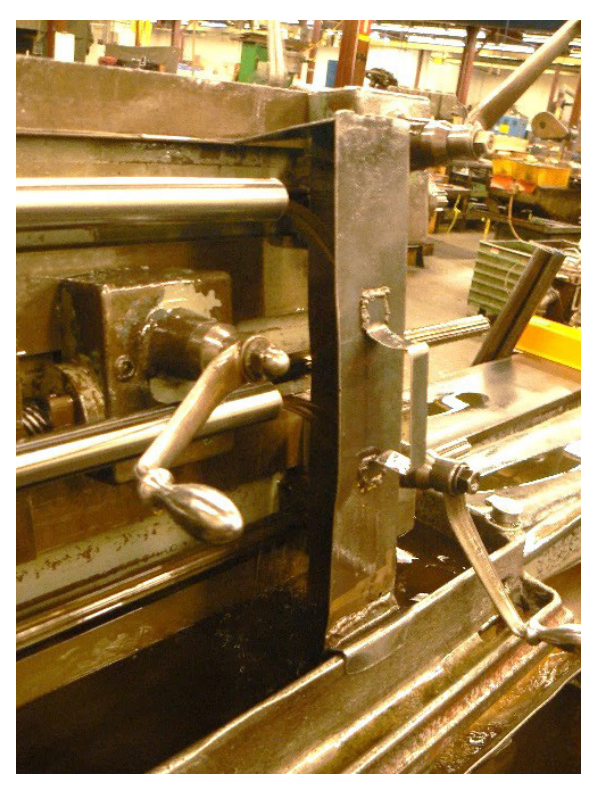

Figure 4. Using the handle, a metal guard is placed over the site on the reaming machine where oil is streaming from the end of metal cylinders. Prior to using this guard, oil splashed from the end of the metal cylinders onto employees.

Between our first and second site visits, the employer trained all production employees on preventing MWF contamination of the skin, and the importance of frequent and thorough skin washing. The training also included information about the effects of MWF exposure on skin, including folliculitis. During informal conversations on our November 2014 site visit, some employees reported washing their hands, forearms, and face more frequently than before the training. 


\section{Metalworking Fluid and Endotoxin Exposures}

Overall, personal thoracic particulate mass exposures ranged from $0.056-0.40 \mathrm{mg} / \mathrm{m}^{3}$. Summary exposure results are shown in Table 2. The highest geometric mean exposures occurred in the chambering department where exposures ranged from $0.23-0.40 \mathrm{mg} / \mathrm{m}^{3}$ and averaged $0.33 \mathrm{mg} / \mathrm{m}^{3}$ of thoracic particulate mass. The highest individual personal exposures occurred in the chambering department $\left(0.40 \mathrm{mg} / \mathrm{m}^{3}\right)$ and milling department $\left(0.39 \mathrm{mg} / \mathrm{m}^{3}\right)$. We compared the air sample results for thoracic-sized particulate to the NIOSH REL. The NIOSH REL does not differentiate between oil-based and water-based MWFs. Of the 43 personal air samples for thoracic particulate over these two shifts, one was at the NIOSH REL of $0.40 \mathrm{mg} / \mathrm{m}^{3}$, the lowest OEL for MWF particulate. Additionally, 15 of the 43 personal air thoracic particulate samples were over $0.2 \mathrm{mg} / \mathrm{m}^{3}$, which is half of the NIOSH REL. These employees worked in chambering, quality control inspection, lathe, milling, maintenance, drilling, and reaming. In the production areas, extracted MWF mass comprised $80 \%$ of total thoracic particulate mass, on average. Individual exposure measurements for thoracic particulate mass and extracted MWF mass can be found in Table B1 in Appendix B.

Table 2. Personal air sampling results for thoracic particulate mass in November 2014

\begin{tabular}{lccc}
\hline Job/Activity & $\begin{array}{c}\text { \# of } \\
\text { samples }\end{array}$ & $\begin{array}{c}\text { Sample duration range } \\
(\mathrm{min})\end{array}$ & $\begin{array}{c}\text { Geometric mean and (range) } \\
\text { concentration } \\
\left(\mathrm{mg} / \mathrm{m}^{3}\right)\end{array}$ \\
\hline Drilling operator & 7 & $449-625$ & $0.18(0.13-0.21)$ \\
Reaming operator & 5 & $574-636$ & $0.18(0.13-0.21)$ \\
Rifling operator & 4 & $524-631$ & $0.15(0.12-0.19)$ \\
Lathe operator & 3 & $360-577$ & $0.23(0.19-0.30)$ \\
Milling operator & 5 & $606-621$ & $0.26(0.15-0.39)$ \\
Chambering operator & 4 & $590-607$ & $0.33(0.23-0.40)$ \\
Quality control inspector & 5 & $516-613$ & $0.17(0.12-0.27)$ \\
Engineer & 2 & $478-525$ & $0.07(0.056-0.08)$ \\
Maintenance & 2 & $542-577$ & $0.21(0.18-0.24)$ \\
Hand grinder & 1 & 624 & 0.21 \\
Oven operator & 2 & $613-614$ & $0.14(0.12-0.16)$ \\
Saws & 1 & 321 & 0.12 \\
\hline NIOSH REL & & & 0.4 \\
\hline
\end{tabular}

Full shift exposures to endotoxin in air ranged from 12-58 endotoxin units per cubic meter of air $\left(\mathrm{EU} / \mathrm{m}^{3}\right)$ (Table B2 in Appendix B). One partial shift (2 hours 17 minutes) exposure was $70 \mathrm{EU} / \mathrm{m}^{3}$. The geometric mean exposure was $24 \mathrm{EU} / \mathrm{m}^{3}$ across nine personal samples. We compared the air sample results for endotoxin to the OEL set by the Dutch Expert Committee on Occupational Safety. There are no OELs for endotoxin in the United States. All samples were below the recommended OEL of $90 \mathrm{EU} / \mathrm{m}^{3}$. The highest endotoxin exposure measurement occurred in the shipping department $\left(70 \mathrm{EU} / \mathrm{m}^{3}\right)$. This was only a partial shift exposure measurement, lasting just over two hours because the employee declined to continue sampling after the lunch break. 
Across the eight bulk MWF samples, endotoxin concentrations ranged from 3.36-598 $\mathrm{EU} / \mathrm{mL}$. There are no exposure limits for endotoxin in bulk MWF. However, the concentrations of endotoxin were not high compared with levels reported in the scientific literature. Simpson and associates found endotoxin ranging from the limit of detection to $1,870,000 \mathrm{EU} / \mathrm{mL}$ in 154 water-based MWF samples; the median was 8,039 EU/mL [Simpson et al. 2003]. In a study of three facilities, Cyprowski et al. [2007] found that the average concentration of bacterial endotoxin in the used MWFs was $773 \mathrm{EU} / \mathrm{mL}$. Endotoxin concentrations ranged from 220 to $1,700 \mathrm{EU} / \mathrm{mL}$ in a manufacturing facility for steel roller bearings [NIOSH 2006].

\section{Questionnaires}

Of the 79 employees who completed a health questionnaire, $68(86 \%)$ were male. The mean age was 43 years (range: $21-65$ years), and the median amount of time worked at the facility was 3 years (range: 1 month-28 years).

The 79 participating employees reported working the most time in the following jobs during the year prior to the questionnaire: 25 in primary manufacturing (including sawing, drilling, reaming, rifling, and quality control), 25 in secondary manufacturing (including CNC lathes, milling, and chambering, and quality control), 18 in other jobs on the manufacturing floor (including machine shop/maintenance, material handler, shipping, clean and inspect, stamping, assembly, and supervisory personnel), and 11 in administrative or clerical jobs.

Of the 79 employees, $70(89 \%)$ reported handling oil, coolant, or parts wet with oil or coolant the week of the survey. Among these 70 employees, 47 (67\%) reported wearing gloves when handling these substances that week (20 always, 13 usually, and 14 sometimes). Of the 70 employees, 23 (33\%) reported that they did not wear gloves the week of the survey when handling oil or coolant, or parts wet with these fluids.

We asked about PPE use during the year prior to the questionnaire. Among the 68 employees who were not administrative or clerical staff, 20 (29\%) reported that they always wore gloves, 13 (19\%) usually, 19 (28\%) sometimes, and 16 (24\%) never. Among employees who reported wearing gloves, they reported that they changed their gloves once per shift on average (range: 0 to 8 times per shift). However, three employees reported changing their gloves only when torn. One employee reported wearing a respirator sometimes while performing work duties, three reported wearing protective sleeves (1 usually, 2 sometimes), and 8 reported wearing aprons (4 always, 1 usually, and 3 sometimes).

The 79 employees reported washing their hands with soap and water 2 to 16 times per shift, with one employee reporting 50 times per shift. Without this employee, the mean was seven times per shift. Seven employees reported using solvents to wash their hands at work, seventeen reported using skin moisturizer at work, and eight reported using barrier creams at work.

Among the 79 participating employees, 23 (29\%) reported dermatitis on some part of their body during the 12 months prior to the questionnaire. Of these 23 employees, 14 reported dermatitis on the wrists or forearms during the prior 12 months, 11 on the hands or fingers, 7 on the face or neck, 5 on the legs or ankles, and 3 on the back or abdomen; 
12 reported dermatitis on more than one body area. Among these 23 employees, 12 reported symptoms that were work-related based on our definition. All 12 employees with workrelated dermatitis reported skin exposure to coolant during the 12-month period; 9 of the 12 also reported skin exposure to oil. No work-related dermatitis was reported among the 16 employees with skin exposure to oil only. Five employees reported having dermatitis on the day of the survey.

To evaluate the relationships between work-related dermatitis and skin contact with oil or coolant, we asked about these exposures during the previous 12 months. Fifty-seven employees reported skin exposure to oil, and 50 reported skin exposure to coolant. Among these employees, 36 reported exposure to both oil and coolant. Only 8 employees reported no oil or coolant exposure to skin (Table 3 ). Work-related dermatitis was reported only by employees who reported skin exposure to coolant (either coolant alone or coolant and oil).

Table 3. Reported skin exposure to MWFs during past 12 months

\begin{tabular}{lcc}
\hline $\begin{array}{l}\text { Reported skin exposure } \\
\left(n=78^{*}\right)\end{array}$ & $\begin{array}{c}\text { Number of employees with } \\
\text { work-related dermatitis }\end{array}$ & $\begin{array}{c}\% \text { of employees with } \\
\text { work-related dermatitis }\end{array}$ \\
\hline Both oil and coolant $(n=36)$ & 9 of 34 & 26 \\
Only coolant $(n=13)$ & 3 of 10 & 30 \\
Only oil $(n=21)$ & 0 of 16 & 0 \\
Neither oil or coolant $(n=8)$ & 0 of 8 & 0 \\
\hline
\end{tabular}

*One employee who reported skin exposure to coolant did not provide data on skin exposure to oil. †Ten employees did not provide data to assess work-related dermatitis.

Table 4 shows results of the analysis of the association between skin exposures and workrelated dermatitis. We found no statistically significant association between skin exposure to oil and work-related dermatitis ( $\mathrm{PR}=1.08,95 \% \mathrm{CI}[0.34,5.38], P=0.99)$. However, we found a statistically significant increase in work-related dermatitis among employees with skin exposure to coolant $(27 \%$, including those with coolant alone plus those with coolant and oil) compared to employees without this exposure $(0 \%)(\mathrm{PR}=$ undefined, $95 \% \mathrm{CI}[1.58$, undefined], $P<0.01)$. We looked at other factors individually to see whether they changed the relationship between skin exposure to oil or coolant and the prevalence of work-related dermatitis, but we found no meaningful changes. These factors included age, sex, smoking status, atopy, glove use, washing hands with solvent, lotion use, barrier cream use, and participating in hobbies with chemical or substance exposures that could affect skin. One difficulty in evaluating the effect of glove use, lotion use, and barrier cream use on dermatitis is that we had no information on whether the employee started using these items before or after developing dermatitis. 
Table 4. Prevalence of work-related dermatitis during past 12 months

\begin{tabular}{lcccc}
\hline Exposure & Yes or No & $\begin{array}{c}\text { No. } \\
\text { employees }\end{array}$ & $\begin{array}{c}\text { No. reporting work- } \\
\text { related dermatitis }(\%)\end{array}$ & $\begin{array}{c}\text { Prevalence ratio } \\
(P \text { value })[95 \% \mathrm{Cl}]\end{array}$ \\
\hline Skin exposure to oil & Yes & 50 & $9(18)$ & $1.08(0.99)$ \\
& No & 18 & $3(17)$ & {$[0.34,5.38]$} \\
Skin exposure to & Yes & 45 & $12(27)$ & Undefined* $(0.01)$ \\
coolant & No & 24 & 0 & {$[1.58$, undefined] } \\
\hline
\end{tabular}

*Denominator of the ratio of prevalences is 0 .

In addition, we found no cases of work-related dermatitis among those reporting no coolant exposure, five cases $(25 \%)$ among those exposed to coolant a few times a week or few times a month, and seven cases (32\%) among those with daily exposure to coolant. In other words, as the frequency of skin exposure to coolant increased, the prevalence of work-related dermatitis significantly increased $(P<0.01)$.

To evaluate the relationship between MWF exposure and respiratory symptoms, we asked participants which job they spent the most time in during the past 12 months. We classified the predominant air exposure (coolant or oil) for each job title on the basis of information and observations from our first site visit. We classified employees working in drilling, reaming, rifling, "clean and inspect," or "primary group leader" jobs as having predominantly air exposure to oil $(\mathrm{n}=22)$, those working with $\mathrm{CNC}$ lathe, $\mathrm{CNC}$ milling, or sawing jobs as having predominantly air exposure to coolant $(\mathrm{n}=17)$, those working in CNC chambering, CNC set up, machine shop/maintenance, material handling, or a job working both saws and primary machines as having air exposure to both oil and coolant $(n=20)$, and the other employees (administrative/clerical employees, engineers, shipping, stamping, assembly, or dipping employees) as having minimal air exposure to oil or coolant $(n=19)$. It is possible for some employees, such as the 19 with minimal air exposure to oil or coolant, to have skin exposure to oil or coolant if they handle parts wet with oil or coolant. We could not classify one employee's job into one of these four categories so did not include him/her in this analysis. Table 5 shows the number and percent of employees reporting respiratory illness or work-related respiratory symptoms in each group. 
Table 5. Employee reports of work-related nasal symptoms, work-related respiratory symptoms, and respiratory illness in the past 12 months, by type of MWF exposure in air $(\mathrm{N}=78)$

\begin{tabular}{|c|c|c|c|c|c|}
\hline Symptom & $\begin{array}{l}\text { Employees in } \\
\text { jobs with } \\
\text { predominantly } \\
\text { coolant } \\
\text { exposure } \\
(\mathrm{n}=17) \\
\text { No. }(\%)\end{array}$ & $\begin{array}{l}\text { Employees in } \\
\text { jobs with } \\
\text { predominantly } \\
\text { oil exposure } \\
(n=22) \\
\text { No. }(\%)\end{array}$ & $\begin{array}{l}\text { Employees in } \\
\text { jobs with both } \\
\text { coolant and oil } \\
\text { exposure } \\
(n=20) \\
\text { No. }(\%)\end{array}$ & $\begin{array}{l}\text { Employees in } \\
\text { jobs with } \\
\text { minimal coolant } \\
\text { and oil } \\
\text { exposure } \\
(n=19) \\
\text { No. }(\%)\end{array}$ & $\begin{array}{l}\text { Statistical } \\
\text { measure: } \\
P \text { value* }\end{array}$ \\
\hline $\begin{array}{l}\text { Work-related } \\
\text { nasal } \\
\text { symptoms } †\end{array}$ & $4(24)$ & $7(32)$ & $6(30)$ & $2(11)$ & 0.38 \\
\hline $\begin{array}{l}\text { Work-related } \\
\text { wheeze }\end{array}$ & $1(6)$ & $4(18)$ & $3(15)$ & $2(11)$ & 0.77 \\
\hline $\begin{array}{l}\text { Work-related } \\
\text { chest tightness }\end{array}$ & 0 & $1(5)$ & 0 & $2(11)$ & 0.39 \\
\hline $\begin{array}{l}\text { Work-related } \\
\text { asthma attack }\end{array}$ & 0 & 0 & 0 & $1(5)$ & 0.46 \\
\hline $\begin{array}{l}\text { Work-related } \\
\text { use of asthma } \\
\text { medication }\end{array}$ & 0 & 0 & 0 & 0 & 1 \\
\hline $\begin{array}{l}\text { Asthma-like } \\
\text { symptoms }\end{array}$ & $3(18)$ & $5(23)$ & $9(45)$ & $2(11)$ & 0.09 \\
\hline $\begin{array}{l}\text { Work-related } \\
\text { asthma-like } \\
\text { symptoms§ }\end{array}$ & $1(6)$ & $4(18)$ & $3(15)$ & $2(11)$ & 0.77 \\
\hline $\begin{array}{l}\text { Pneumonia or } \\
\text { flu }\end{array}$ & $2(12)$ & $2(9)$ & 0 & $5(26)$ & 0.07 \\
\hline
\end{tabular}

${ }^{*} P$ value compares the difference in the percent of symptoms for the four groups. A $P$ value $<0.05$ is considered statistically significant.

†Work-related symptoms were defined as symptoms that improved away from work.

$\ddagger$ Asthma-like symptoms were defined as any of the following: current use of asthma medicine, wheezing or whistling in the chest in the past 12 months, awakening with a feeling of chest tightness in the past 12 months, or attack of asthma in the past 12 months.

§Work-related asthma-like symptoms were defined as having one or more of the following: less use of asthma medicine when away from work, wheezing or whistling in the chest in the past 12 months that improves away from work, awakening with a feeling of chest tightness in the past 12 months that improves away from work, or attacks of asthma in the past 12 months that are less frequent away from work. Employees reporting work-related asthma-like symptoms are a subset of those reporting asthma-like symptoms.

When we looked at employee groups based on the categories in Table 5, we found that the work-related nasal and respiratory symptom percentages were not significantly different between the groups. Work-related nasal symptoms were reported more than other workrelated respiratory symptoms. Employees reporting work-related asthma-like symptoms are included among the employees reporting asthma-like symptoms. Two employees reporting work-related asthma-like symptoms also reported having flu or pneumonia during the same year. It is possible that the asthma-like symptoms were related to having a respiratory infection, although we would not expect the symptoms to improve away from work. 
When we looked at only production employees $(n=65)$, we found $10(14 \%)$ employees reporting work-related asthma-like symptoms (by our definition) and 19 (29\%) reporting work-related nasal symptoms. Production employees included those with jobs predominantly on the production floor: sawing, drilling, reaming, rifling, CNC lathe, CNC milling, $\mathrm{CNC}$ chambering, CNC set up, machine shop/maintenance, material handling, clean and inspect, dipping, stamping, assembly, shipping, primary group lead and QC team lead. Non production employees included administrative, clerical, engineering, and administrative assistant $(\mathrm{n}=13)$.

\section{Post-shift Health Survey}

Over our 2-day evaluation, 30 employees completed 48 post-shift surveys, 29 on the first day and 19 on the second day. Eighteen employees participated both days, eleven participated the first day only, and one participated the second day only. Eight of the 30 employees reported one or more new-onset symptoms; all eight reported new-onset runny nose. Runny nose was the most common new-onset symptom employees reported $(n=10)$ (Table 6).

Table 6. Results of post-shift symptom surveys over 2 days ( $n=48$ surveys)

\begin{tabular}{lccc}
\hline Symptom & $\begin{array}{c}\text { Number of times } \\
\text { symptom was } \\
\text { reported at } \\
\text { end of shift }\end{array}$ & $\begin{array}{c}\text { Number of times } \\
\text { symptom was } \\
\text { reported at } \\
\text { start of shift* }\end{array}$ & $\begin{array}{c}\text { Number of times } \\
\text { symptom was reported } \\
\text { at end, but not start, } \\
\text { of work shift }\end{array}$ \\
\hline Runny nose & 15 & 5 & 10 \\
Nasal congestion & 6 & 4 & 2 \\
Persistent cough & 6 & 4 & 2 \\
Shortness of breath & 2 & 1 & 1 \\
Chest tightness & 2 & 1 & 1 \\
Wheezing & 3 & 2 & 1 \\
Irritated eyes & 3 & 2 & 1 \\
Skin redness on & 2 & 0 & 1 \\
hands, wrists, or arms & & & \\
\hline
\end{tabular}

*If post-shift symptom was not present, we did not ask about pre-shift symptom.

\section{Comparing Post-shift Symptom Survey Results with Metalworking Fluid Sampling Results}

We looked at new-onset symptoms during the work shift in relation to MWF concentration in air during the same shift. We were able to analyze only the relationship between new-onset runny nose and MWF concentration; the numbers were too small for this analysis for the other new-onset symptoms. We did not find a relationship between new-onset runny nose and concentrations of MWF in air. 


\section{Discussion}

Results from our initial evaluation (August 2014) found skin exposure to oil as the likely cause of work-related dermatitis among employees. However, on the basis of our questionnaire findings from our second site visit (November 2014), employee reports of skin contact with coolant, but not oil, were significantly associated with work-related dermatitis. The difference in findings between our first and second site visits is likely due to a variety of factors:

1. Preventive measures were introduced after our first site visit. Splash guards were installed on reaming machines to prevent oil splashes and we saw an increased use of tools to remove oil-coated chips in the primary department, rather than manual removal techniques.

2. Employee training was held after our first site visit, which led to improvements in employee skin hygiene and work practices, and increased use of PPE. This training may have been emphasized to primary employees since the primary area was the one with the most skin problems at the time.

3. Different methods of data collection were used. During our first site visit, two NIOSH investigators interviewed employees using a semi-structured interview form with openended questions. During the second visit, self-administered questionnaires were completed by the employees. The questionnaire asked more in-depth questions about symptoms.

4. Recall bias may have occurred. During the first site visit, employees reporting dermatitis the year prior to the interview may have forgotten about their bout of dermatitis at the time of the second site visit.

5. A modest decrease in production occurred between our first and second site visits, so fewer employees made fewer parts, resulting in reduced dermal and respiratory exposures.

6. An increase in production during 2012 and 2013 may have led to higher exposures during this time period, particularly in the primary area where machines are not enclosed and do not have mist collectors. Additionally, newly hired employees may have had less experience in avoiding oil exposure to their skin (through proper work practices and consistent PPE use) and removing oil from their skin regularly through frequent and thorough hand hygiene. The OSHA Logs and workers' compensation claim records included several employees who no longer worked at the company during our visits.

7. In the fall of 2013, the plant changed to a new type of oil-based MWF. Since dermatitis can sometimes take months to resolve, employees who may have developed a rash from the old oil would have responded yes when asked about rash in the year prior to August 2014. The new oil may have led to a reduction in dermatitis among primary department employees which was observed in our second site visit (November 2014).

Employees working on CNC machines also had skin exposure to the corrosion inhibitor, Cimguard 10. We did not ask about exposure to the anticorrosion product on our questionnaire, so we do not know if exposure to this corrosion inhibitor, to the coolant, or to both, led to dermatitis. However, we observed that nearly all employees who worked 
on CNC machines manually dipped their machined parts into the Cimguard 10, and some employees did not wear gloves when performing this work task. According to the safety data sheet, Cimguard 10 can cause defatting, drying, and irritation of the skin. The manufacturer recommends that employees wear nitrile gloves when handling this product to prevent skin problems. We also found, based on our observations and questionnaire data, that most employees with skin exposure to oil, coolant, or both, did not wear gloves or protective sleeves adequately to protect their skin. Skin contact with MWF may cause allergic contact dermatitis, irritant contact dermatitis, or oil folliculitis (irritation or infection of hair follicles) depending on the chemical composition, additives and contaminants, type of metal being machined, and the exposed individual's tendency for developing allergies [Chew and Maibach 2003; Slodownik et al. 2008; WISHA 2001]. Limiting skin exposure is critical to preventing allergic and irritant disorders and folliculitis related to MWF exposure. Studies have shown that about one in four employees diagnosed with occupational contact dermatitis will have persistent symptoms despite treatment or job change [Cretkovski et al. 2006; Jungbauer et al. 2004]. Additional information about contact dermatitis and tips to reduce or prevent work-related contact dermatitis are given in Appendix C.

Although the HHE request did not include concerns about respiratory symptoms, our experience at other plants using MWFs has shown that employees with MWF exposure generally report both skin and respiratory symptoms. This plant was no different. Work-related nasal, respiratory, and asthma-like symptoms were reported by production employees in this plant and were likely related to coolant and/or oil exposures. This, paired with measurements showing historical and current MWF concentrations that meet or exceed the NIOSH REL, indicate additional measures are needed to reduce airborne exposures on the production floor to prevent these work-related symptoms. Appendix A includes additional information about MWF health effects. Our findings are consistent with other studies which show nasal symptoms are commonly reported among MWF-exposed employees [Park et al. 2008].

One MWF mist level we measured was at the NIOSH REL and some MWF mist levels were above half of the REL. NIOSH recommends more frequent air sampling when MWF air exposures are more than half the REL. The highest levels were found in the CNC chambering and milling departments. We measured several MWF air levels close to half of the REL in the primary area during our visit. The company sampling records indicated that MWF exposure levels varied during 2008-2014. The causes of these variations are difficult to pinpoint, but are likely related to changes in exposure controls in the workplace and variations in control performance, work practices, hygiene, and production levels. The NIOSH REL is intended to prevent or greatly reduce respiratory disorders associated with MWF exposure. Limiting exposure to MWF aerosols is also prudent because previous exposures to some MWF have been associated with increased risk of some types of cancer. Although actions taken by the manufacturing industry in the last several decades have reduced that risk, it is not known if these actions have eliminated the risk [NIOSH 2013].

We know that employees can develop respiratory symptoms when exposed to MWF levels below the NIOSH OELs [NIOSH 1998]. One study found significantly more upper and lower respiratory symptoms among employees exposed to a mean value of total MWF aerosols of $0.4 \mathrm{mg} / \mathrm{m}^{3}$, which is below the NIOSH REL for total MWF aerosols of $0.5 \mathrm{mg} / \mathrm{m}^{3}$, 
compared to unexposed employees [Lillienberg et al. 2010]. Park et al. studied an auto parts manufacturing employee population; 61\% of MWF-exposed employees reported rhinitisrelated symptoms. Air sampling found that $82 \%$ of employees at this facility were exposed to total MWF levels at or below $0.5 \mathrm{mg} / \mathrm{m}^{3}$ [Park et al. 2008]. Looking at the general population, Guerra et al. found rhinitis (defined as runny or stuffy nose or episodes of sneezing apart from a cold) to be a significant risk factor for adult-onset asthma in those with and without history of allergies [Guerra et al. 2002]. The majority of production employees who reported respiratory symptoms at your facility were exposed to MWF air levels below the REL. Overall, the best way to prevent upper and lower respiratory symptoms and diseases among MWF-exposed employees is to keep MWF levels as low as feasible. Additionally, employees exposed to MWF would benefit from medical monitoring and any employee reporting asthma-like symptoms needs to be medically evaluated.

Shipping employees, who we considered minimally exposed to airborne MWF, reported work-related respiratory symptoms. We cannot determine the cause(s) of these symptoms with certainty, based on the exposures we evaluated. A partial-shift endotoxin exposure measurement for one shipping employee was high; although the sampled exposure for this employee may not reflect full shift exposure, endotoxin exposure may be contributing to respiratory symptoms among employees in this work area. Endotoxin has been found in agricultural dusts (cotton, grain, potato, peanut processing plants; animal barns and compost bins), in contaminated water systems (metalworking fluids; paper, nylon, and fiberglass manufacturing plants), office and home dust (likely from pools of water in heating and ventilation systems), and cigarette smoke [Reed and Milton 2001]. In your facility, coolant is a likely source of endotoxin exposure, with the endotoxin settling onto surfaces over time. Exposure to endotoxin has been shown to cause respiratory symptoms [DECOS 2010; Reed and Milton 2001]. Additional information on endotoxin exposure limits and health effects are discussed in Appendix A. Other possible exposures in the shipping department may include gasoline and diesel vehicle exhaust when trucks deliver raw materials to the shipping bay or when finished materials are trucked away from the facility. Since this evaluation focused on the evaluation of metalworking fluid exposures, finding work-related respiratory symptoms among shipping employees was unexpected since they were not directly involved in production. When work-related symptoms are newly identified, jobs in which employees are experiencing symptoms should be evaluated for exposures and work characteristics that may be contributing factors.

The higher rates of illnesses and injuries in this facility compared to the U.S. small arms manufacturing industry identifies a need to further improve prevention measures. The majority of injury and illness entries were marked as musculoskeletal strains and sprains.

\section{Conclusions}

Reduced production levels and changes made in the plant in 2013-2014 - including switching to a different oil and improving exposure controls, training, work practices, and hygiene - have reduced the risk of dermatitis from oil-based MWFs. However, we found a significant association between skin exposure to coolant and work-related dermatitis. Co-exposure to the corrosion inhibitor may have been an important contributing factor. 
Employees with work-related respiratory symptoms were exposed to airborne MWF levels that have been known to cause or exacerbate respiratory symptoms, although the exposures are at or below NIOSH-recommended limits. Actions are needed to protect employees from developing or exacerbating dermal and respiratory problems related to MWF and other chemical exposures in the plant.

\section{Recommendations}

On the basis of our findings, we recommend the actions listed below. We encourage the rifle barrel manufacturing company to use a labor-management health and safety committee or working group to discuss our recommendations and develop an action plan. Those involved in the work can best set priorities and assess the feasibility of our recommendations for the specific situation at the facility.

Our recommendations are based on an approach known as the hierarchy of controls. This approach groups actions by their likely effectiveness in reducing or removing hazards. In most cases, the preferred approach is to eliminate hazardous materials or processes and install engineering controls to reduce exposure or shield employees. Until such controls are in place, or if they are not effective or feasible, administrative measures and PPE may be needed.

\section{Engineering Controls}

Engineering controls reduce employees' exposures by removing the hazard from the process or by placing a barrier between the hazard and the employee. Engineering controls protect employees effectively without placing primary responsibility of implementation on the employee.

1. Change the chip removal procedures in the drilling department to reduce dermal MWF exposure. This may include providing small shovels, dust pans, or vacuums and discouraging employees from pulling chips from the machine or collection bins by hand.

2. Provide baskets or other tools for employees to use when dipping parts into the corrosion inhibitor (Cimguard 10). Until baskets can be provided, require employees to use nitrile gloves when manually dipping parts into the Cimguard 10. The glove cuff should be long enough to prevent dermal exposure to both MWF and Cimguard 10 while working.

3. Provide all employees with high friction mats at their work stations to prevent slips and falls in locations where regular cleaning is not sufficient.

\section{Administrative Controls}

The term administrative controls refers to employer-dictated work practices and policies to reduce or prevent hazardous exposures. Their effectiveness depends on employer commitment and employee acceptance. Regular monitoring and reinforcement are necessary to ensure that policies and procedures are followed consistently.

1. Establish a comprehensive preventive MWF maintenance program, as specified in Chapter 9 of the NIOSH document, "Criteria for a Recommended Standard: 
Occupational Exposure to Metalworking Fluids" [NIOSH 1998]. This includes cleaning machines thoroughly before adding clean MWF and cleaning and maintaining mist collectors regularly. If the maintenance program does not consistently reduce airborne MWF exposure below half the NIOSH REL, install additional mist collectors on chambering and milling CNC machines and replace lower capacity mist collectors with higher capacity mist collectors. Do not rely on poor performance and visible MWF mist in the production floor air to determine when mist impingers and electronic cells in the mist collector should be cleaned. The mist collectors used at the site can also be installed on CNC machines that use coolant. More information about the function and maintenance of MWF mist collectors can be found in OSHA's "Metalworking Fluids: Safety and Health Best Practices Manual" at the following website: https://www.osha.gov/SLTC/metalworkingfluids/metalworkingfluids manual.html.

2. Consult with the MWF manufacturers to identify best practices for MWF maintenance, including change-out and cleaning schedules. If not properly maintained, the recycling reservoirs in CNC machines can harbor undesirable and unexpected bacteria. Proper maintenance is particularly important to maintain coolant quality. The manufacturer of the coolant used at this facility recommends cleaning coolant systems and replacing used coolant annually [Blaser Swisslube Inc. 2013].

3. Encourage drilling, reaming, and rifling employees to use work practices and tools to prevent oil from spilling onto to the floors and walkways when removing metal chips, transferring parts to and from the machines, and transporting parts between departments. Ensure that normal equipment operation doesn't cause oil to splash onto the floor or onto aprons.

4. Implement an exposure monitoring program for MWF in air. All employees exposed to MWF should be included in the air monitoring program. Perform exposure monitoring annually in each department where MWF is used and at least every 6 months in departments where exposures have exceeded one half of the NIOSH REL. The NIOSH MWF RELs are $0.40 \mathrm{mg} / \mathrm{m}^{3}$ for thoracic particulate and $0.5 \mathrm{mg} / \mathrm{m}^{3}$ for total particulate. Notify workers of all sampling results and monitor exposed workers more frequently until at least two consecutive samples indicate that exposures no longer exceed the REL. Additionally, perform personal MWF air monitoring when significant process changes have been made or production levels have changed.

5. Start a medical monitoring program for employees who are exposed to MWFs. Periodic use of a medical questionnaire that focuses on skin and respiratory symptoms may be helpful. The questionnaire should be given prior to placement in a job with MWF exposure and periodically thereafter. Questionnaire responses can help identify work areas and tasks that need additional evaluation and employees who need additional medical follow-up. A medical monitoring program helps prevent, identify, and manage skin and respiratory disease among included employees. It includes preplacement or initial examination, periodic examination, detailed examination for a subset of employees, physician's reports, and follow-up evaluations. More information about medical monitoring and its implementation can be found in the NIOSH document "What You Need to Know About Occupational Exposure to Metalworking 
Fluids" at https://www.cdc.gov/niosh/docs/98-116/pdfs/98-116.pdf.

6. Assess respiratory hazards in the departments where shipping employees work. Identify and evaluate respiratory exposures, existing ventilation, and workplace practices that may be contributing to work-related asthma-like symptoms among shipping department employees.

7. Prohibit employees from using solvents to clean their skin. Provide non-irritating cleaning agents and soaps at wash stations for employees to use.

8. Encourage employees to report all potential work-related skin or respiratory problems to their supervisors. Employees with persistent symptoms should be evaluated by an occupational medicine physician or a medical provider specializing in workplace illnesses. The Association of Occupational and Environmental Clinics has an online directory of such providers at http://www.aoec.org/directory.htm. Employees with definite or possible occupational skin or respiratory diseases should be protected from exposures to substances that cause or exacerbate the disease. In some cases of allergic contact dermatitis, allergic occupational asthma, and hypersensitivity pneumonitis, employees may have to be reassigned with retention of pay and employment status to areas where exposure is minimal or nonexistent.

9. Encourage employees to discuss their work exposures with their primary healthcare provider and to share any exposure sampling records and any health concerns with him or her.

10. Train all employees who will be handling MWF on the proper handling and use of MWF and on the hazards and potential health effects associated with MWF exposure upon entering the workforce and annually thereafter. Include information on how to avoid skin irritation, such as by washing their arms up to the elbows whenever they wash their hands at work. Also include information on how to carefully select moisturizers, soaps, and skin cleaners because some components such as lanolin and fragrances are known allergens and may cause allergic contact dermatitis in sensitive individuals. Guidelines for MWF training are included in the NIOSH document "What You Need to Know about Occupational Exposure to Metalworking Fluids" at https:// www.cdc.gov/niosh/docs/98-116/pdfs/98-116.pdf.

11. When considering a change in MWFs, corrosion inhibitors, or other products used in production, consider the potential impact on employee respiratory and dermal health. As part of managing health risks of product changes, consult with the product manufacturers about reported health risks, perform exposure monitoring to carefully monitor the impact of the change of product on exposures, and closely monitor changes in employee-reported health effects. As part of a comprehensive health and safety program, all new processes, process changes, or product changes should be evaluated for new exposures or changes in exposures.

12. Clean surfaces in the plant periodically to reduce and prevent dust and other particulate buildup. Wet wiping or using a vacuum with a high efficiency particulate air (HEPA) air filter would be appropriate; avoid dry sweeping because it can cause settled materials to be kicked up into the air. 
13. Monitor injury and illness logs routinely to identify particular job duties, work materials, machines, or areas of the plant that may be associated with high numbers of workplace injuries and illnesses. Focus on these areas for preventive actions. For example, OSHA has guidelines for preventing musculoskeletal strains and sprains. They can be found at https://www.osha.gov/SLTC/ergonomics/controlhazards.html.

14. Do not turn on the radiant overhead heaters for the first time in the cold season when employees are present. Before a forecast of cold weather, turn on the radiant heaters when the building is unoccupied to prevent smoke exposure to employees.

\section{Personal Protective Equipment}

PPE is the least effective means for controlling hazardous exposures. Proper use of PPE requires a comprehensive program and a high level of employee involvement and commitment. The right PPE must be chosen for each hazard. Supporting programs such as training, change-out schedules, and medical assessment may be needed. PPE should not be the sole method for controlling hazardous exposures. Rather, PPE should be used until effective engineering and administrative controls are in place.

1. Provide new employees with non-personalized work uniforms for temporary use until they reach the employment benchmark of 90 days, at which time they could receive the personalized uniforms.

2. Improve access to gloves so employees can change their gloves when needed. For example, have gloves available in each work area. Production employees should have a new pair of disposable gloves every shift and change gloves when they are damaged and at lunch breaks. Educate employees that reusing gloves increases the risk of contaminating the inside of the gloves, which would result in dermal MWF exposure and possible skin problems.

3. Try multiple styles of longer cuffed gloves that are easier to remove without rolling down the cuff. Ensure that chosen gloves are of the appropriate material and thickness to prevent cuts during metal chip handling. Involving employees in the selection process will help ensure that the selected gloves will be used properly.

4. Require CNC machining employees to use gloves to protect their hands from the corrosion inhibitor (Cimguard 10) until dipping baskets or dipping tools are available. 


\section{Appendix A: Occupational Exposure Limits and Health Effects}

NIOSH investigators refer to mandatory (legally enforceable) and recommended OELs for chemical, physical, and biological agents when evaluating workplace hazards. OELs have been developed by federal agencies and safety and health organizations to prevent adverse health effects from workplace exposures. Generally, OELs suggest levels of exposure that most employees may be exposed to for up to 10 hours per day, 40 hours per week, for a working lifetime, without experiencing adverse health effects. However, not all employees will be protected if their exposures are maintained below these levels. Some may have adverse health effects because of individual susceptibility, a pre-existing medical condition, or a hypersensitivity (allergy). In addition, some hazardous substances act in combination with other exposures, with the general environment, or with medications or personal habits of the employee to produce adverse health effects. Most OELs address airborne exposures, but some substances can be absorbed directly through the skin and mucous membranes.

Most OELs are expressed as a time-weighted average (TWA) exposure. A TWA refers to the average exposure during a normal 8- to 10-hour workday. Some chemical substances and physical agents have recommended short-term exposure limits ceiling values. Unless otherwise noted, the short-term exposure limit is a 15-minute TWA exposure. It should not be exceeded at any time during a workday. The ceiling limit should not be exceeded at any time.

In the United States, OELs have been established by federal agencies, professional organizations, state and local governments, and other entities. Some OELs are legally enforceable limits; others are recommendations.

- The U.S. Department of Labor OSHA permissible exposure limits (29 CFR 1910 [general industry]; 29 CFR 1926 [construction industry]; and 29 CFR 1917 [maritime industry]) are legal limits. These limits are enforceable in workplaces covered under the Occupational Safety and Health Act of 1970.

- NIOSH RELs are recommendations based on a critical review of the scientific and technical information and the adequacy of methods to identify and control the hazard. NIOSH RELs are published in the NIOSH Pocket Guide to Chemical Hazards [NIOSH 2010]. NIOSH also recommends risk management practices (e.g., engineering controls, safe work practices, employee education/training, PPE, and exposure and medical monitoring) to minimize the risk of exposure and adverse health effects.

- Other OELs commonly used and cited in the United States include the threshold limit value (TLVs), which are recommended by American Conference of Governmental Industrial Hygienists (ACGIH), a professional organization, and the workplace environmental exposure levels (WEELs), which are recommended by the American Industrial Hygiene Association, another professional organization. The TLVs and WEELs are developed by committee members of these associations from a review of the published, peer-reviewed literature. These OELs are not consensus standards. TLVs are considered voluntary exposure guidelines for use by industrial hygienists and others 
trained in this discipline "to assist in the control of health hazards" [ACGIH 2016]. WEELs have been established for some chemicals "when no other legal or authoritative limits exist" [AIHA 2016].

Outside the United States, OELs have been established by various agencies and organizations and include legal and recommended limits. The Institut für Arbeitsschutz der Deutschen Gesetzlichen Unfallversicherung (Institute for Occupational Safety and Health of the German Social Accident Insurance) maintains a database of international OELs from European Union member states, Canada (Québec), Japan, Switzerland, and the United States. The database, available at http://www.dguv.de/ifa/GESTIS/GESTIS-Internationale-Grenzwerte-fürchemische-Substanzen-limit-values-for-chemical-agents/index-2.jsp, contains international limits for more than 2,000 hazardous substances and is updated periodically.

OSHA requires an employer to furnish employees a place of employment free from recognized hazards that cause or are likely to cause death or serious physical harm [Occupational Safety and Health Act of 1970 (Public Law 91-596, sec. 5(a)(1))]. This is true in the absence of a specific OEL. It also is important to keep in mind that OELs may not reflect current health-based information.

When multiple OELs exist for a substance or agent, NIOSH investigators generally encourage employers to use the lowest OEL when making risk assessment and risk management decisions. NIOSH investigators also encourage use of the hierarchy of controls approach to eliminate or minimize workplace hazards. This includes, in order of preference, the use of (1) substitution or elimination of the hazardous agent, (2) engineering controls (e.g., local exhaust ventilation, process enclosure, dilution ventilation), (3) administrative controls (e.g., limiting time of exposure, employee training, work practice changes, medical surveillance), and (4) PPE (e.g., respiratory protection, gloves, eye protection, hearing protection). Control banding, a qualitative risk assessment and risk management tool, is a complementary approach to protecting employee health. Control banding focuses on how broad categories of risk should be managed. Information on control banding is available at http://www.cdc.gov/niosh/topics/ctrlbanding/. This approach can be applied in situations where OELs have not been established or can be used to supplement existing OELs.

\section{Metalworking Fluids}

Metalworking fluids are complex mixtures used to cool, lubricate, and remove metal chips from tools and parts during machining of metal stock. Most straight oils are highly refined products of petroleum stocks and do not contain water. Other types of MWFs (soluble, semisynthetic, and synthetic) are water-based mixtures that may require dilution. Metalworking fluids often contain other substances, including biocides, corrosion inhibitors, metal fines, tramp oils, and biological contaminants [Burton et al. 2012; NIOSH 1998]. MWFs may increase in temperature, depending on the heat created by the process and the composition of the MWF. Inhalation of MWF aerosols may irritate the throat, nose, and lungs and has been associated with chronic bronchitis, asthma, hypersensitivity pneumonitis, and worsening of pre-existing respiratory problems [Burton et al. 2012]. NIOSH recommends limiting exposures to MWF aerosols to $0.4 \mathrm{mg} / \mathrm{m}^{3}$ for the thoracic particulate mass, as a 
TWA concentration, for up to 10 hours per day during a 40-hour workweek. However, some workers have developed work-related asthma or hypersensitivity pneumonitis at MWF exposures below the NIOSH recommended exposure level, so maintaining MWF levels below the REL is best practice [NIOSH 1998].

Skin contact with MWF may cause allergic contact dermatitis or irritant contact dermatitis, depending on the chemical composition, additives and contaminants, type of metal being machined, and the exposed individual's tendency for developing allergies [WISHA 2001]. Synthetic, semisynthetic, and soluble oil MWF are diluted with water, so excess bacteria may grow if MWF is not properly monitored and maintained. The Health and Safety Executive in the United Kingdom states that well-maintained MWF should have bacterial concentrations below $10^{3} \mathrm{CFU} / \mathrm{mL}$ of fluid [HSE 2006]. Concentrations between $10^{3}$ and $10^{6} \mathrm{CFU} / \mathrm{mL}$ indicate reasonable control, and concentrations greater than $10^{6} \mathrm{CFU} / \mathrm{mL}$ indicate poor control [HSE 2006].

The NIOSH REL is intended to prevent or greatly reduce respiratory disorders associated with MWF exposure. In addition, limiting dermal (skin) exposure is critical to preventing allergic and irritant disorders related to MWF exposure. NIOSH recommends that all employees exposed to MWF at over half the REL receive medical monitoring, and all employees with exposure to MWF may benefit from medical monitoring [NIOSH 1998]. Supervision of the medical monitoring program should be done by a physician or other health professional with expertise in the identification and management of MWF-related respiratory conditions and skin diseases.

\section{Endotoxin}

The outer cell walls of Gram-negative bacteria may release lipopolysaccharide compounds called endotoxin when the bacteria die or multiply. Endotoxin is believed to cause adverse respiratory effects such as chronic bronchitis and asthma. In 2010, the Dutch Expert Committee on Occupational Safety recommended a health-based OEL for airborne endotoxin of $90 \mathrm{EU} / \mathrm{m}^{3}$ as an 8-hour TWA [DECOS 2010]. No accepted OELs have been developed in the United States because of the variability of sampling and analytical methods, and because of a lack of data showing a consistent dose-response relationship. 


\section{Appendix B: Detailed Personal Exposure Measurements}

Table B1. Individual thoracic particulate and extracted MWF full-shift exposure measurements

\begin{tabular}{|c|c|c|c|c|c|c|}
\hline Job title & $\begin{array}{l}\text { Day } 1 \\
\text { sample } \\
\text { time } \\
(\min )\end{array}$ & $\begin{array}{l}\text { Day } 1 \\
\text { total thoracic } \\
\text { particulate } \\
\left(\mathrm{mg} / \mathrm{m}^{3}\right)\end{array}$ & $\begin{array}{c}\text { Day } 1 \\
\text { extracted } \\
\text { MWF } \\
\text { particulate } \\
\left(\mathrm{mg} / \mathrm{m}^{3}\right) \\
\end{array}$ & $\begin{array}{l}\text { Day } 2 \\
\text { sample } \\
\text { time } \\
(\min )\end{array}$ & $\begin{array}{c}\text { Day } 2 \\
\text { total } \\
\text { thoracic } \\
\text { particulate } \\
\left(\mathrm{mg} / \mathrm{m}^{3}\right)\end{array}$ & $\begin{array}{c}\text { Day } 2 \\
\text { extracted } \\
\text { MWF } \\
\text { particulate } \\
\left(\mathrm{mg} / \mathrm{m}^{3}\right)\end{array}$ \\
\hline $\begin{array}{l}\text { Chambering CNC } \\
\text { operator }\end{array}$ & 607 & $0.37^{*}$ & 0.34 & 592 & $0.23^{*}$ & 0.17 \\
\hline $\begin{array}{l}\text { Chambering CNC } \\
\text { operator }\end{array}$ & 603 & $0.34^{*}$ & 0.30 & 590 & $0.40 \dagger$ & 0.33 \\
\hline Drilling operator & 449 & 0.17 & 0.15 & - & - & - \\
\hline Drilling operator & 591 & $0.21^{*}$ & 0.20 & 523 & $0.20^{*}$ & 0.16 \\
\hline Drilling operator & 612 & 0.17 & 0.10 & 618 & 0.13 & 0.093 \\
\hline Drilling operator & 622 & $0.21^{*}$ & 0.19 & 625 & 0.15 & 0.12 \\
\hline $\begin{array}{l}\text { Drilling quality } \\
\text { control inspector }\end{array}$ & 613 & 0.27 & 0.22 & - & - & - \\
\hline Engineer & 478 & {$[0.056]$} & {$[0.055]$} & 525 & {$[0.077]$} & {$[0.027]$} \\
\hline Hand grinder & - & - & - & 624 & $0.21^{*}$ & 0.17 \\
\hline Lathe operator & 420 & $0.21^{*}$ & 0.16 & 577 & 0.19 & 0.15 \\
\hline Lathe operator & 491 & $0.30^{*}$ & 0.20 & - & - & - \\
\hline $\begin{array}{l}\text { Lathe quality } \\
\text { control inspector }\end{array}$ & 547 & 0.17 & 0.14 & 516 & 0.13 & 0.12 \\
\hline Maintenance & 577 & 0.18 & 0.090 & 542 & $0.25^{*}$ & 0.18 \\
\hline Milling CNC operator & 612 & 0.13 & 0.10 & 621 & $0.39^{*}$ & 0.34 \\
\hline Milling CNC operator & 606 & 0.15 & 0.11 & - & - & - \\
\hline Milling CNC operator & - & - & - & 610 & $0.35^{*}$ & 0.15 \\
\hline Milling CNC operator & 617 & $0.25^{*}$ & 0.15 & - & - & - \\
\hline Oven operator & 614 & 0.16 & 0.12 & 613 & 0.12 & 0.10 \\
\hline Reaming operator & 574 & 0.19 & 0.20 & - & - & - \\
\hline Reaming operator & 632 & $0.20^{*}$ & 0.16 & 623 & 0.15 & 0.11 \\
\hline Reaming operator & 636 & $0.21^{*}$ & 0.19 & 623 & 0.13 & 0.084 \\
\hline Rifling operator & 614 & 0.19 & 0.16 & 516 & 0.12 & {$[0.075]$} \\
\hline Rifling operator & 611 & 0.13 & 0.12 & 524 & 0.16 & 0.12 \\
\hline Rifling operator & 616 & 0.15 & 0.14 & 631 & 0.15 & 0.13 \\
\hline $\begin{array}{l}\text { Rifling quality } \\
\text { control inspector }\end{array}$ & 600 & 0.17 & 0.12 & 602 & 0.12 & 0.12 \\
\hline Saw operator & 431 & 0.12 & 0.12 & - & - & - \\
\hline \multicolumn{7}{|c|}{$\mathrm{NIOSH}$ Recommended Exposure Limit for total thoracic particulate is $0.4 \mathrm{mg} / \mathrm{m}^{3}$} \\
\hline \multicolumn{7}{|c|}{ - The compound was not sampled for on this day } \\
\hline \multicolumn{7}{|c|}{$\begin{array}{l}\text { [ ] The concentration was between the minimum detectable concentration and the minimum } \\
\text { quantifiable concentration and there is more uncertainty associated with this value; the minimal } \\
\text { quantifiable concentration ranged from } 0.074 \text { to } 0.11 \mathrm{mg} / \mathrm{m}^{3} \text { for extracted MWF fraction and } \\
0.075 \text { to } 0.11 \mathrm{mg} / \mathrm{m}^{3} \text { for total thoracic particulate }\end{array}$} \\
\hline \multicolumn{7}{|c|}{$\begin{array}{l}{ }^{*} \text { The exposure is at least one half of the NIOSH REL } \\
\text { †The exposure meets the NIOSH REL }\end{array}$} \\
\hline
\end{tabular}


Table B2. Individual full-shift endotoxin exposure concentrations

\begin{tabular}{lcccc}
\hline Job title & $\begin{array}{c}\text { Day 1 } \\
\text { endotoxin } \\
\left(\mathrm{EU} / \mathrm{m}^{3}\right)\end{array}$ & $\begin{array}{c}\text { Day 1 } \\
\text { sample time } \\
(\mathrm{min})\end{array}$ & $\begin{array}{c}\text { Day 2 } \\
\text { endotoxin } \\
\left(\mathrm{EU} / \mathrm{m}^{3}\right)\end{array}$ & $\begin{array}{c}\text { Day 2 } \\
\text { sample time } \\
(\mathrm{min})\end{array}$ \\
\hline Lathe operator & 17 & 579 & - & - \\
Milling CNC operator & - & - & 38 & 595 \\
Milling CNC operator & 58 & 1 & - & - \\
Hand grinder & 12 & 462 & - & - \\
Shipping & $70^{*}$ & 137 & - & - \\
Milling CNC operator & 21 & 500 & - & - \\
CNC set up & 28 & 544 & - & 615 \\
Safety & 15 & 577 & 13 & \\
\hline
\end{tabular}

- The compound was not sampled for in air on this day

*This sample was partial-shift (2 hours 17 minutes) 


\section{Appendix C: Contact Dermatitis}

Contact dermatitis makes up $90 \%$ to $95 \%$ of all occupational skin diseases [Ingber and Merims 2004; Lushniak 2004]. Contact dermatitis, both irritant and allergic, is an inflammatory skin condition caused by skin contact with agents such as chemical irritants (irritant contact dermatitis) or allergens (allergic contact dermatitis). Irritant contact dermatitis is skin inflammation due to direct cell damage from a chemical or physical agent, while allergic contact dermatitis is a delayed immune reaction. Over 57,000 chemicals are reported to cause skin irritation, but only 3,700 chemicals are known skin allergens [Belsito 2005]. Usually, only a small percentage of people are susceptible to skin allergens.

In contact dermatitis, the skin initially turns red and can develop bumps and small, oozing blisters. After several days, crusts and scales form. Stinging, burning, and itching often occur. With no further contact with the agent, the dermatitis usually disappears in 1 to 3 weeks. With chronic exposure, deep fissures, scaling, and darkening of the skin can occur. Exposed areas of the skin, such as hands and forearms, have the greatest contact with irritants or allergens and are most commonly affected. Over $80 \%$ of occupational contact dermatitis involves the hands [Belsito 2005; Flyvholm et al. 2007; Warshaw et al. 2003]. If the agent gets on clothing, it can bring on dermatitis at areas of greatest contact, such as thighs, upper back, armpits, and feet. Dusts can produce dermatitis at areas where the dust accumulates and is held in contact with the skin, such as under the collar and belt line, at the tops of socks or shoes, and in skin creases, such as inside elbows and behind knees. Mists can produce dermatitis on the face and neck. Irritants and allergens can be transferred to distant areas of the body, such as the trunk or genitalia, by unwashed hands or from areas of accumulation, such as under rings or in finger webs.

It is often impossible to clinically distinguish irritant contact from allergic contact dermatitis, as both can have a similar appearance and both can result in an acute, subacute, or chronic condition. Irritant contact dermatitis can be caused by many factors. The most common skin irritant at work is wet work, defined as exposure of skin to liquid for more than 2 hours per day, use of occlusive gloves for more than 2 hours per day, or frequent hand washing [Chew and Maibach 2003; Slodownik et al. 2008]. Other common causes of irritant contact dermatitis include soaps and detergents, solvents, food products, cleaning agents, plastics and resins, petroleum products and lubricants, metals, and machine oils and coolants [Chew and Maibach 2003; Slodownik et al. 2008]. Frictional irritant contact dermatitis can be caused by low humidity, heat, paper, tools, metals, fabrics, plastics, fibrous glass and other particulate dusts, and cardboard, among other causes [McMullen and Gawkrodger 2006; Morris-Jones et al. 2002]. Causes of allergic contact dermatitis include plants (e.g., poison ivy), metallic salts, germicides, plastic resins, rubber additives, and fragrances [Mathias 1990]. In patients with occupational contact dermatitis who were skin-patch tested, the most common relevant allergens included thiuram mix, carba mix, bacitracin, methyldibromo glutaronitrile/ phenoxyethanol, formaldehyde, glutaraldehyde, methylmethacrylate, nickel, cobalt, and chromium [Warshaw et al. 2007, 2008].

Studies on the prognosis of occupational contact dermatitis stress the importance of primary prevention. One study found that $32 \%$ of 124 surveyed patients had severe hand dermatitis 
5 years after they were initially diagnosed with irritant hand dermatitis. Severity was measured by self-reported frequency of relapses, frequency of dermatologist visits, and use of topical corticosteroids [Jungbauer et al. 2004]. Another study found that $25 \%$ of 540 surveyed patients had persistently severe or aggravated symptoms 1 year after initial diagnosis of occupational hand dermatitis. Poor prognosis was associated with the presence of atopic dermatitis and being 25 years of age or older. Prognosis was not affected by whether the dermatitis was irritant or allergic. Those with severe occupational hand dermatitis at baseline had a higher risk of taking sick leave and job loss in the following year than those with mild cases. The study found no significant improvement in the disease after the change of job [Cvetkovski et al. 2006]. Widespread hand dermatitis on initial examination was found to be the greatest factor for a poor long-term prognosis in a third study [Meding et al. 2005]. In addition, many skin disorders, including contact dermatitis, have been shown to have a significant impact on quality of life [Cvetkovski et al. 2005; Fowler et al. 2006; Kadyk et al. 2003; Lan et al. 2008].

\section{Prevention of Contact Dermatitis}

Avoiding irritants and allergens, in addition to wet work, is the first step in dermatitis prevention. Liberal use of skin moisturizers helps to prevent contact dermatitis by maintaining a healthy skin barrier, and also helps to repair this barrier if it has been compromised [Chew and Maibach 2003]. The following list provides strategies in the prevention of occupational contact dermatitis:

$\circ$ Identifying irritants and allergens

- Substituting chemicals that are less irritating or allergenic

- Establishing engineering controls to reduce exposure

- Emphasizing personal and occupational hygiene

- Establishing educational programs to increase awareness in the workplace

- Using PPE, such as gloves and special clothing [NIOSH 1988]

Chemical changes in industrial materials have been beneficial. For example, the addition of ferrous sulfate to cement to reduce the hexavalent chromium content has been effective in reducing occupational allergic contact dermatitis in Europe [Goh and Gan 1996]. Protective gloves can reduce or eliminate skin exposure to hazardous substances if used correctly, but may actually cause or worsen hand dermatitis (by permeation and penetration) if selected poorly and used improperly (by contamination) [Foo et al. 2006]. The use of PPE may occlude irritants or allergens next to the skin, and PPE components may directly irritate the skin. Therefore, the correct use of PPE is at least as important as the correct selection of materials [Kwon et al. 2006]. Similarly, the excessive pursuit of personal hygiene in the workplace may actually lead to misuse of soaps and detergents and cause irritant contact dermatitis. Proper hand washing methods and adequate moisturizing are valuable in preventing contact dermatitis [Warshaw 2003]. The effectiveness of barrier creams is controversial because data on the protective nature of these topical products during actual working conditions involving high-risk exposures are limited. Educating the workforce about 
skin care, exposures, and PPE use is an especially important measure in the prevention of occupational contact dermatitis [Loffler et al. 2006; Schwanitz et al. 2003; Weisshaar et al. 2006]. The following list provides tips on proper hand washing [Warshaw et al. 2003]:

- Avoid hot water; use lukewarm or cool water instead.

- Use mild cleansers without perfume, coloring, or antibacterial agents.

- Pat hands dry, especially between fingers.

- Apply skin moisturizer generously after hand washing and repeat throughout the day.

- Avoid rubbing, scrubbing, the use of washcloths, and the overuse of soap and water.

This additional list provides tips for the workplace [Warshaw et al. 2003]:

- Remove rings before work.

- Wear protective gloves in cold weather and for dusty work.

- Wear tight-fitting leather gloves for frictional exposures.

- When performing wet work, wear cotton gloves under vinyl or other nonlatex gloves.

- Avoid immersing hands; use running water if possible. 


\section{References}

ACGIH [2016]. 2016 TLVs ${ }^{\circledR}$ and BEIs ${ }^{\circledR}$ : threshold limit values for chemical substances and physical agents and biological exposure indices. Cincinnati, OH: American Conference of Governmental Industrial Hygienists.

AIHA [2016]. AIHA 2016 emergency response planning guidelines (ERPG) \& workplace environmental exposure levels (WEEL) handbook. Fairfax, VA: American Industrial Hygiene Association.

Air Quality Engineering [2016]. MistBuster ${ }^{\circledR}$ 500, 850 and 2000 installation and operation manual. Minneapolis, MN: Air Quality Engineering.

ANSI/ISEA [2011]. American National Standard for Hand Protection Classification. American National Standards Institute/ISEA standard 105-2011. Arlington, VA: International Safety Equipment Association.

Belsito DV [2005]. Occupational contact dermatitis: etiology, prevalence, and resultant impairment/disability. J Am Acad Dermatol 53(2):303-313.

Blaser Swisslube Inc. [2010]. MSDS Blasocut BC40SW, http://www.blaser.com/index.cfm?type=start\&navid=382\&land=us.

Blaser Swisslube Inc. [2013]. Blasocut BC40SW Maintenance. Goshen, NY: Blaser Swisslube.

BLS [2016]. Bureau of Labor Statistics occupational injuries and illnesses incidence rate calculator and comparison tool webpage, http://data.bls.gov/iirc/. Tabular data for years 2011, 2012, 2013, 2014: total number of nonfatal work-related injury and illness cases, number of cases involving days away from work, and number of cases involving job transfer or restricted work activity only, by industry.

Burton CM, Crook B, Scaife H, Evans GS, Barber CM [2012]. Systematic review of respiratory outbreaks associated with exposure to water based metalworking fluids. Ann Occup Hyg 56(4):374-388.

Cambrex [2005]. Limulus Amebocyte Lysate (LAL), Kinetic-QCL. Catalog Number: 50650U. Walkersville, MD.

Chew AI, Maibach HI [2003]. Occupational issues of irritant contact dermatitis. Int Arch Occup Environ Health 76(5):339-346.

CFR. Code of Federal Regulations. Washington, DC: U.S. Government Printing Office, Office of the Federal Register.

Cvetkovski RS, Rothman KJ, Olsen J, Mathiesen B, Iversen L, Johansen JD, Agner T [2005]. Relation between diagnoses on severity, sick leave and loss of job among patients with occupational hand eczema. Br J Dermatol 152(1):93-98. 
Cvetkovski RS, Zachariae R, Jensen H, Olsen J, Johansen JD, Agner T [2006]. Prognosis of occupational hand eczema: a follow-up study. Arch Dermatol 142(3):305-311.

Cyprowski M, Piotrowska M, Zakowska Z, Szadkowska-Stańczyk I [2007]. Microbial and endotoxin contamination of water-soluble metalworking fluids. Int J Occup Med Environ Health 20(4):365-371.

DECOS [2010]. Endotoxins: health-based recommended occupational exposure limit. The Hague: Health Council of the Netherlands, Dutch Expert Committee on Occupational Safety, https://www.gezondheidsraad.nl/sites/default/files/201004OSH.pdf.

Eisen EA, Picciotto S, Robins JM [2013]. Healthy worker effect. Encyclopedia of environmetrics.

Flyvholm MA, Bach B, Rose M, Jepsen KF [2007]. Self-reported hand eczema in a hospital population. Contact Dermatitis 57(2):110-115.

Foo CC, Goon AT, Leow YH, Goh CL [2006]. Adverse skin reactions to personal protective equipment against severe acute respiratory syndrome--a descriptive study in Singapore. Contact Dermatitis 55(5):291-294.

Fowler JF, Ghosh A, Sung J, Emani S, Chang J, Den E, Thorn D, Person J, Duh MS [2006]. Impact of chronic hand dermatitis on quality of life, work productivity, activity impairment, and medical costs. J Am Acad Dermatol 54(3):448-457.

Goh CL, Gan SL [1996]. Change in cement manufacturing process, a cause for decline in chromate allergy? Contact Dermatitis 34(1):51-54.

Grassi M, Rezzani C, Biino G, Marinoni A [2003]. Asthma-like symptoms assessment through ECRHS screening questionnaire scoring. J Clin Epidemiol 56(3):238-247.

Guerra S, Sherrill DL, Martinez FD, Barbee RA [2002]. Rhinitis as an independent risk factor for adult-onset asthma. J Allergy Clin Immunol 109(3):419-425.

HSE (Health and Safety Executive) [2006]. Managing sumps and bacterial contamination control approach 4. COSHH essentials for machining with metalworking fluids, http://www.hse.gov.uk/pubns/guidance/mw05.pdf.

Ingber A, Merims S [2004]. The validity of the Mathias criteria for establishing occupational causation and aggravation of contact dermatitis. Contact Dermatitis 51(1):9-12.

Jungbauer FH, van der Harst JJ, Groothoff JW, Coenraads PJ [2004]. Skin protection in nursing work: promoting the use of gloves and hand alcohol. Contact Dermatitis 51(3):135-140.

Kadyk DL, McCarter K, Achen F, Belsito DV [2003]. Quality of life in patients with allergic contact dermatitis. J Am Acad Dermatol 49(6):1037-1048.

Kwon S, Campbell LS, Zirwas MJ [2006]. Role of protective gloves in the causation and treatment of occupational irritant contact dermatitis. J Am Acad Dermatol 55(5):891-896. 
Lan CC, Feng WW, Lu YW, Wu CS, Hung ST, Hsu HY, Yu HS, Ko YC, Lee CH, Yang YH, Chen GS [2008]. Hand eczema among University Hospital nursing staff: identification of high-risk sector and impact on quality of life. Contact Dermatitis 59(5):301-306.

Lillienberg L, Andersson EM, Järvholm B, Torén K [2010]. Respiratory symptoms and exposure-response relations in workers exposed to metalworking fluid aerosols. Ann Occup Hyg 54(4):403-411.

Loffler H, Bruckner T, Diepgen T, Effendy I [2006]. Primary prevention in health care employees: a prospective intervention study with a 3-year training period. Contact Dermatitis 54(4):202-209.

Lushniak BD [2004]. Occupational contact dermatitis. Dermatol Ther 17(3):272-277.

Mathias CGT [1990]. Prevention of occupational contact dermatitis. J Am Acad Dermatol 23(4 Pt 1):742-748.

McMullen E, Gawkrodger DJ [2006]. Physical friction is under-recognized as an irritant that can cause or contribute to contact dermatitis. Br J Dermatol 154(1):154-156.

Meding B, Wrangsjo K, Jarvholm B [2005]. Fifteen-year follow-up of hand eczema: predictive factors. J Invest Dermatol 124(5):893-897.

Morris-Jones R, Robertson SJ, Ross JS, White IR, McFadden JP, Rycroft RJ [2002]. Dermatitis caused by physical irritants. Br J Dermatol 147(2):270-275.

NIOSH [1988]. Proposed national strategy for the prevention of leading work-related diseases and injuries: dermatological conditions. Cincinnati, OH: U.S. Department of Health and Human Services, Centers for Disease Control, National Institute for Occupational Safety and Health, DHHS (NIOSH) Publication No. 89-136.

NIOSH [1998]. Criteria for a recommended standard: occupational exposure to metalworking fluids. Cincinnati, OH: U.S. Department of Health and Human Services, Centers for Disease Control and Prevention, National Institute for Occupational Safety and Health, DHHS (NIOSH) Publication No. 98-102.

NIOSH [2006]. Evaluation of exposures at steel roller bearing facility. By Rodriguez M, Eisenberg J. Cincinnati, OH: U.S. Department of Health and Human Services, Centers for Disease Control and Prevention, National Institute for Occupational Safety and Health, NIOSH Health Hazard Evaluation Report 2004-0399-3007, https:/www.cdc.gov/niosh/hhe/reports/pdfs/2004-0399-3007.pdf.

NIOSH [2010]. NIOSH pocket guide to chemical hazards. Cincinnati, OH: U.S. Department of Health and Human Services, Centers for Disease Control and Prevention, National Institute for Occupational Safety and Health, DHHS (NIOSH) Publication No. 2010-168c, http://www.cdc.gov/niosh/npg/. 
NIOSH [2013]. Metalworking fluids. Cincinnati, OH: U.S. Department of Health and Human Services, Centers for Disease Control and Prevention, National Institute for Occupational Safety and Health, https://www.cdc.gov/niosh/topics/metalworking/.

NIOSH [2016]. NIOSH manual of analytical methods (NMAM®). 5th ed. O'Connor PF, Ashley K, eds. Cincinnati, OH: U.S. Department of Health and Human Services, Centers for Disease Control and Prevention, National Institute for Occupational Safety and Health, DHHS (NIOSH) Publication No. 2014-151, http://www.cdc.gov/niosh/nmam/.

Park DU, Jin KW, Koh DH, Kim BK, Kim KS, Park DY [2008]. Association between use of synthetic metalworking fluid and risk of developing rhinitis-related symptoms in an automotive ring manufacturing plant. J Occup Health 50(2):212-220.

Reed CE, Milton DK [2001]. Endotoxin-stimulated innate immunity: a contributing factor for asthma. J Allergy Clin Immunol 108(2):157-166.

Schwanitz HJ, Riel U, Schlesinger T, Bock M, Skudlik C, Wulfhorst B [2003]. Skin care management: educational aspects. Int Arch Occup Environ Health 76(5):374-381.

Simpson AT, Stear M, Groves JA, Piney M, Bradley SD, Stagg S, Crook B [2003]. Occupational exposures to metalworking fluid mist and sump fluid contaminants. Ann Occup Hyg 47(1):17-30.

Slodownik D, Lee A, Nixon R [2008]. Irritant contact dermatitis: a review. Australas J Dermatol 49(1):1-9.

Susitaival P, Flyvholm MA, Meding B, Kanerva L, Lindberg M, Svensson A, Olafsson JH [2003]. Nordic Occupational Skin Questionnaire (NOSQ-2002): a new tool for surveying occupational skin diseases and exposure. Contact Dermatitis 49(2):70-76.

Warshaw E, Lee G, Storrs FJ [2003]. Hand dermatitis: a review of clinical features, therapeutic options, and long-term outcomes. Am J Contact Dermat 14(3):119-137.

Warshaw EM, Ahmed RL, Belsito DV, DeLeo VA, Fowler JF, Maibach HI, Marks JG, Mathias CG, Pratt MD, Rietschel RL, Sasseville D, Storrs FJ, Taylor JS, Zug KA [2007]. Contact dermatitis of the hands: cross-sectional analyses of North American Contact Dermatitis Group Data, 1994-2004. J Am Acad Dermatol 57(2):301-314.

Warshaw EM, Schram SE, Maibach HI, Belsito DV, Marks JG, Fowler JF, Rietschel RL, Taylor JS, Mathias CG, DeLeo VA, Zug KA, Sasseville D, Storrs FJ, Pratt MD [2008]. Occupation-related contact dermatitis in North American health care workers referred for patch testing: cross-sectional data, 1998-2004. Dermatitis 19(5):261-274.

Weisshaar E, Radulescu M, Bock M, Albrecht U, Diepgen TL [2006]. Educational and dermatological aspects of secondary individual prevention in healthcare workers. Contact Dermatitis 54(5):254-260.

WISHA [2001]. Preventing occupational dermatitis. Olympia, WA: Washington State Department of Labor and Industries, Safety \& Health Assessment \& Research for Prevention (SHARP) Publication No. 56-01-1999. 
Keywords: North American Industry Classification System 332994 (Small Arms, Ordnance, and Ordnance Accessories Manufacturing), New Hampshire, metalworking fluids, MWFs, respiratory, dermatitis, coolant, mineral oil, rifles, guns 
The Health Hazard Evaluation Program investigates possible health hazards in the workplace under the authority of the Occupational Safety and Health Act of 1970 (29 U.S.C. § 669(a) (6)). The Health Hazard Evaluation Program also provides, upon request, technical assistance to federal, state, and local agencies to investigate occupational health hazards and to prevent occupational disease or injury. Regulations guiding the Program can be found in Title 42, Code of Federal Regulations, Part 85; Requests for Health Hazard Evaluations (42 CFR Part 85).

\section{Disclaimer}

The recommendations in this report are made on the basis of the findings at the workplace evaluated and may not be applicable to other workplaces.

Mention of any company or product in this report does not constitute endorsement by NIOSH.

Citations to Web sites external to NIOSH do not constitute NIOSH endorsement of the sponsoring organizations or their programs or products. NIOSH is not responsible for the content of these Web sites. All Web addresses referenced in this document were accessible as of the publication date.

\section{Acknowledgments}

Analytical Support: Bureau Veritas North America

Desktop Publisher: Shawna Watts

Editor: Ellen Galloway

Industrial Hygiene Field Assistance: Karl Feldmann, Leonard Zwack

Logistics: Donnie Booher, Kevin Moore

Medical Field Assistance: Sophia Chiu, Kerton Victory

Data Support: Denise Giglio

\section{Availability of Report}

Copies of this report have been sent to the employer and employees at the facility. The state and local health department and the Occupational Safety and Health Administration Regional Office have also received a copy. This report is not copyrighted and may be freely reproduced.

\section{Recommended citation for this report:}

NIOSH [2016]. Evaluation of metalworking fluid exposure and dermatitis among rifle barrel manufacturing employees. By Tapp LC, Broadwater K, Mueller CA. Cincinnati, OH: U.S. Department of Health and Human Services, Centers for Disease Control and Prevention, National Institute for Occupational Safety and Health, NIOSH Health Hazard Evaluation Report 2014-0170-3263, http://www.cdc.gov/niosh/hhe/reports/pdfs/2014-0170-3263.pdf. 
Delivering on the Nation's promise:

Safety and health at work for all people through research and prevention

To receive NIOSH documents or more information about occupational safety and health topics, please contact NIOSH:

Telephone: 1-800-CDC-INFO (1-800-232-4636)

TTY: 1-888-232-6348

CDC INFO: www.cdc.gov/info

or visit the NIOSH Web site at www.cdc.gov/niosh

For a monthly update on news at $\mathrm{NIOSH}$, subscribe to $\mathrm{NIOSH}$ eNews by visiting www.cdc.gov/niosh/eNews. 